\title{
Eradication of Transboundary Animal Diseases: Can the Rinderpest Success Story be Repeated?
}

\author{
G. R. Thomson ${ }^{1,2, *}$, G. T. Fosgate ${ }^{3}$ and M.-L. Penrith ${ }^{1,2}$ \\ ${ }^{1}$ TAD Scientific, Pretoria, South Africa \\ ${ }^{2}$ Department of Veterinary Tropical Diseases, Faculty of Veterinary Science, University of Pretoria, \\ Onderstepoort, South Africa \\ ${ }^{3}$ Department of Production Animal Studies, Faculty of Veterinary Science, University of Pretoria, \\ Onderstepoort, South Africa \\ G. R. Thomson. TAD Scientific, P O Box 1607, Brooklyn Square, Pretoria 0075, South Africa.
}

${ }^{*}$ Correspondence:

E-mail: gavin@tadscientific.co.za

\section{ABSRACT}

A matrix system was developed to aid in the evaluation of the technical amenability to eradication, through mass vaccination, of transboundary animal diseases. The system involved evaluation of three basic criteria - disease management efficiency-, surveillance- and epidemiological factors each in turn comprised of a number of elements (17 in all). On that basis, 25 TADs that occur in southern Africa and for which vaccines are available, in addition to rinderpest (incorporated as a yard-stick because it has been eradicated world-wide), were ranked. Cluster analysis was also applied using the same criteria to the 26 diseases, resulting in their division into three clusters. One cluster contained only diseases transmitted by arthropods (such as bluetongue \& African horsesickness), and considered difficult to eradicate because technologies for managing parasitic arthropods on a large scale are unavailable, while a second cluster contained diseases that have been widely considered to be eradicable (rinderpest, canine rabies, the Eurasian serotypes of foot and mouth disease virus [O, A, C \& Asia 1] and peste des petits ruminants) as well classical swine fever, Newcastle disease and lumpy skin disease. The third cluster contained all the other TADs evaluated with the implication that these constitute TADs that would be more difficult to eradicate. However, it is acknowledged that the scores assigned in the course of this study may be biased. The point is that the system proposed offers an objective method for assessment of eradicability of TADs; the rankings and groupings derived during this study are less important than the provision a systematic approach for further development and evaluation.

\section{INTRODUCTION}

The ideal of human disease eradication - defined by Hopkins (2013) as zero occurrence of disease globally resulting from deliberate effort - is universally considered desirable for humanitarian reasons. The incentive for eradication of animal diseases is different, founded mainly on concerns for food security and economics. In such cases the balance between benefits and costs is crucial and may include non-financial costs such as those to the environment occasioned by intervention strategies (Thomson et al., 2013a). 
To date two diseases have been declared eradicated globally, namely smallpox in 1980 (WHO 1980; Dowdle 1998) and rinderpest in 2011 (OIE 2011; Roeder 2011). The biological factors that enabled the eradication of smallpox and rinderpest included the fact that the pathogen was directly transmitted (i.e. contagious), maintained by a single species ${ }^{1}$ in which the clinical signs were severe and typical and accompanied by a high mortality rate and, in individuals that did not succumb to the infection induced lifelong immunity to re-infection. Furthermore, effective diagnostic tools and vaccines were available (Anon 2013; Dowdle 1998; Miller et al. 2006; Roeder 2011).

A number of other human diseases have, at various times been prioritised for eradication, viz. dracunculiasis (Guinea worm disease), lymphatic filariasis (elephantiasis), measles, mumps, poliomyelitis, rubella, and taeniasis/cysticercosis caused by the pork tapeworm, Taenia solium (Carter Center 2008). However, currently there are only two diseases for which eradication campaigns are 'officially sanctioned' (dracunculiasis \& poliomyelitis) and one (lymphatic filariasis) against which the World Health Organisation (WHO) has a 'designated campaign' (Hopkins, 2013). Although it is recognised that eradication of diseases transmitted biologically by arthropod vectors is challenging, global eradication of malaria remains a goal for WHO (Miller, 2006; Mendis et al. 2009; Liu et al. 2013;; Anon, 2013). It has been contended that while most diseases can be controlled, very few human diseases are candidates for eradication and for many, perhaps the majority, there are scientific factors that make eradication impossible irrespective of other considerations (Miller et al., 2006).

The eradication of rinderpest prompted interest in eradicating other transboundary animal diseases (TADs) and towards the end of the rinderpest eradication campaign contagious bovine pleuropneumonia (CBPP) was under consideration as the next-most serious disease affecting cattle in Africa (Windsor 2000; Amanfu 2009; Marobela-Raborokgwe 2011). However, the proposal to eradicate CBPP was to a large extent superseded by a decision on the part of the Food and Agriculture Organisation of the UN (FAO) and the World Organisation for Animal Health (OIE) to work towards progressively controlling foot and mouth disease (FMD) with the ultimate objective of eradication. Subsequently the objective was modified to progressive control with a view to eventually purging livestock of this infection worldwide (OIE 2012; OIE/FAO 2012; Weaver et al. 2013). The reason for confinement of the objective to livestock species was that in some regions of the world, sub-Saharan Africa specifically, particular serotypes of FMD virus (SATs) are maintained by wildlife populations (Thomson et al., 2003; Wakesa et al., 2013). For that reason eradication of these serotypes is problematic. The Eurasian serotypes of FMD virus have nevertheless been eradicated from some regions of the world such as western Europe through mass vaccination up to 1990, followed by introduction of a non-vaccination policy (Sutmoller et al., 2003). Good progress in this direction has also been achieved in South America (www.oie.int/en/for-the-media/pressreports/2004-2000/previous-press-releases/eradication -of-foot-and-mouth-disease-in-theAmericas/).

Peste des petits ruminants (PPR), has recently been proposed for eradication, mainly because it is an escalating problem in both Africa and Asia and the causative agent is a morbillivirus closely related to the rinderpest virus (Baron et al., 2011; Albina et al., 2012; Libeau et al., 2014). However, there

\footnotetext{
${ }^{1}$ In the case of rinderpest, although species other than cattle were susceptible to infection and development of disease, long-term maintenance of the infection was dependent on cattle
} 
are a number of features of PPR which are likely to render it more difficult to eradicate than rinderpest (Roeder 2011, 2012; Libeau et al., 2014). Classical swine fever has also been considered in the context of eradication although progress in that respect has not been apparent (Edwards et al., 2000). Canine rabies has also proven amenable to regional elimination through mass vaccination of dogs, a good example being the USA (http://www.cdc.gov/news/2007/09/canine rabies.htm).

At the Dahlen Workshop on the eradication of infectious diseases held in 1997, technical considerations essential for rendering human infectious diseases eradicable were identified (Dowdle 1998). These have been modified and expanded upon here to make them applicable to transboundary animal diseases (TADs), viz: (1) an effective intervention is available and able to reduce the effective reproductive number to less than $1\left(R_{t}<1\right),(2)$ surveillance tools and strategies with sufficient sensitivity and specificity are available to detect levels of infection that can lead to transmission, (3) the definitive domestic animal host(s) is/are essential for the life-cycle of the agent, (4) the involvement of free-living invertebrate and/or vertebrate vectors in the life-cycle of the infectious agent and (5) the ability of the agent to persist or multiply in the environment in the absence of an animal host.

Apart from technical considerations, eradication initiatives are also determined by socio-economic factors that affect the willingness of governments and civil society to invest the money and organisational effort required to derive long-lasting benefit from eradication of specific diseases (Dowdle 1998; Miller et al. 2006; Hopkins, 2013). That is dependent upon the actual or perceived impact of the disease in question, which may differ between regions of the world. For example, the perceived impact or threat posed FMD is very different between developed countries where intensive livestock production is vital to the economy (e.g. Australia, Europe and North America) and southern and East Africa where livestock farming is much less intensive (Thomson, 2009).

On the other hand, regional disparity in the impact of specific TADs and the consequent perceived need to eradicate them tends to be countered by the need for uniformity imposed by trade standards designed to promote free trade (i.e. the fundamental objective of the World Trade Organisation [WTO]). Sanitary standards devoted to measures for ensuring food safety and prevention of animal disease spread through commodities and products derived from animals may influence rural development profoundly (Thomson et al., 2013a). These standards - one set for food safety and the other for management of animal disease spread - are developed by international standard-setting bodies acting on behalf of the WTO's Sanitary and Phytosanitary Committee which administers the Agreement on the Application of Sanitary and Phytosanitary Measures (SPS Agreement - www.wto.org/english/tratop e/spsagr e.htm). A fundamental objective of SPS Agreement is 'harmonization' as articulated by Article 3 of that Agreement. The animal health standards for trade in animal commodities are set by the OIE (one for terrestrial- and the other for aquatic animals), are based fundamentally on the need to ensure that the locality of production of animal commodities is free from TADs. The rationale for this is that disease spread by commodities derived from animals has a negligible risk of occurring if the infection concerned is not present in the locality of production. Consequently, sanitary trade standards represent a powerful incentive for disease eradication, be it at local (i.e. for zones), country, regional or global levels. This requirement for 'disease-freedom' often results in trade bans on countries or zones that are not recognised as free from specific TADs. The consequence is that if a disease is not technically eradicable, local 
producers and traders are faced with an insoluble problem. The inevitable result of such situations is that in some regions of the world sanitary trade standards appear irrational (Thomson et al., 2013a).

There is little doubt that compliance with trade standards for trade access is the single biggest driver of disease eradication initiatives. This is because sanitary standards for managing animal disease hazards, unlike those for food safety, are currently predominantly focused on ensuring that commodities and products are derived from animals raised in localities recognised as being free from trade-influencing TADs (Thomson et al., 2013b). This is unnecessary because there are other ways than those based on the geographic distribution of an infection by which the animal disease risks associated with trade can be effectively managed (Thomson et al., 2004; FAO, 2011; Thomson et al., 2013b). Non-geographic standards are essential for localities where TADs cannot be eradicated for technical reasons. That, of course, does not imply that safety standards should be lower where eradication is impossible; just different.

In this study we have attempted to develop a systematic method for assessing and comparing the technical eradicability of TADs using a matrix approach in order to introduce a more objective approach for initiatives aimed at disease eradication. To test the system, we evaluated 26 TADs against which vaccines are available, on their relative amenability to eradication based on mass vaccination programmes, i.e. similar to that applied historically to rinderpest. An attempt was also made to determine which technical factors are most influential in determining the eradicability of TADs.

\section{MATERIALS AND METHODS}

\section{Disease assessment}

Based on the five technical considerations listed in the introduction, three technical criteria were considered in relation to eradication of individual diseases: (1) the nature and effectiveness of the intervention strategy available (based on mass vaccination for a period of time sufficient to effectively abrogate transmission of the infection), (2) adequacy of surveillance tools and strategies for detection of the infectious agent in question and (3) features of the epidemiology of each disease which either favour or militate against potential eradicability. Each of these primary criteria were considered to be comprised of a number of elements (Table 1). Because, as explained below, different elements are not equally important in contributing to overall eradicability, the elements were weighted (1-10: 1 = low impact on eradication; 10 = high impact on eradication), based on the opinion of the authors. In that way a matrix was developed through which selected TADs could be compared to assess relative amenability to eradication based on technical considerations (Table 2).

The 26 TADs were selected on the basis that they are 'listed' by the OIE (www.oie.int), are diseases that have significant impact in southern Africa and against which one or more vaccines are available. Rinderpest was included because although it has not for many years had any impact in southern Africa it was shown to be eradicable. FMD resulting from infection with Eurasian serotype lineage $(O$, A, C \& Asia 1) and canine rabies were also considered as base-line cases because all have proven amenable regional eradication (sometimes referred to as elimination - Hopkins, 2013). All criteria were scored by the authors using a scale of 1-5 ( 1 = criterion poorly satisfied for the disease; $5=$ criterion highly satisfied for the disease). This was repeated for each of 26 selected diseases (Table 3). 
Table 1: Tranboundary animal diseases evaluated in this study

\begin{tabular}{|l|c|}
\hline \multicolumn{1}{|c|}{ Disease } & $\begin{array}{c}\text { Number/letter } \\
\text { identification }\end{array}$ \\
\hline African horse sickness (AHS) & $12 / \mathrm{L}$ \\
\hline Anthrax & $1 / \mathrm{A}$ \\
\hline Blue tongue (BT) & $3 / \mathrm{C}$ \\
\hline Bovine anaplasmosis (BA) & $24 / \mathrm{Y}$ \\
\hline Bovine babesiosis (BB) & $22 / \mathrm{V}$ \\
\hline Bovine tuberculosis (BTB) & $5 / \mathrm{E}$ \\
\hline Canine rabies (CR) & $17 / \mathrm{Q}$ \\
\hline Caprine brucellosis (Brucella melitensis - CB) & $7 / \mathrm{G}$ \\
\hline Classical swine fever (CSF) & $2 / \mathrm{B}$ \\
\hline Contagious bovine pleuropneumonia (CBPP) & $14 / \mathrm{N}$ \\
\hline Contagious caprine pleuropneumonia (CCPP) & $6 / \mathrm{F}$ \\
\hline East Coast fever (ECF) & $16 / \mathrm{P}$ \\
\hline Equine herpesvirus 1 infection (EHV-1) & $8 / \mathrm{H}$ \\
\hline Equine influenza (EI) & $10 / \mathrm{J}$ \\
\hline Foot and mouth disease - Eurasian serotypes (FMD-E) & $11 / \mathrm{K}$ \\
\hline Foot and mouth disease - SAT serotypes (FMD-S) & $9 / \mathrm{I}$ \\
\hline Haemorrhagic septicaemia (HS) & $26 / \mathrm{Z}$ \\
\hline Heartwater (HW) & $13 / \mathrm{M}$ \\
\hline Infectious bursal disease (IBD) & $23 / \mathrm{W}$ \\
\hline Infectious bovine rhinotracheitis (IBR) & $20 / \mathrm{T}$ \\
\hline Lumpy skin disease (LSD) & $18 / \mathrm{R}$ \\
\hline Newcastle disease (NCD) & $25 / \mathrm{Y}$ \\
\hline Paratuberculosis (ParaTB) & $15 / \mathrm{O}$ \\
\hline Peste des petits rumainants (PPR) & $4 / \mathrm{D}$ \\
\hline Rinderpest & $21 / \mathrm{U}$ \\
\hline Rift Valley fever (RVF) & $19 / \mathrm{S}$ \\
\hline
\end{tabular}


Table 2: Factors and elements - with weighting - related to TADs eradicability

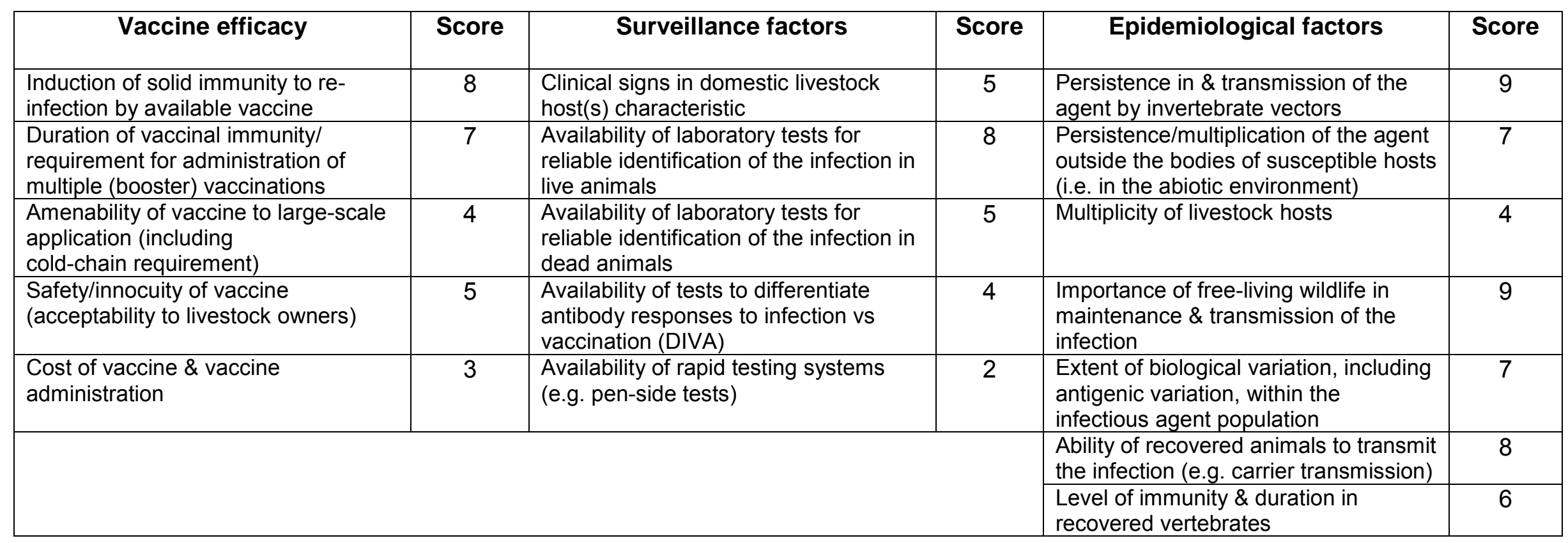


Table 3: Scores for elements accorded to individual TADs

\section{Anthrax}

\begin{tabular}{|c|c|c|c|c|c|}
\hline Disease management efficacy & Score & Surveillance factors & Score & Epidemiological factors & Score \\
\hline $\begin{array}{l}\text { Induction of solid immunity to } \\
\text { infection by available vaccine }\end{array}$ & 3 & $\begin{array}{l}\text { Clinical signs in domestic livestock } \\
\text { host(s) characteristic }\end{array}$ & 3 & $\begin{array}{l}\text { Persistence in \& transmission of the } \\
\text { agent by invertebrate vectors }\end{array}$ & 5 \\
\hline $\begin{array}{l}\text { Duration of vaccinal immunity/ } \\
\text { requirement for administration of } \\
\text { multiple (booster) vaccinations }\end{array}$ & 3 & $\begin{array}{l}\text { Availability of laboratory tests for } \\
\text { reliable identification of the infection } \\
\text { in live animals }\end{array}$ & 1 & $\begin{array}{l}\text { Persistence/multiplication of the agent } \\
\text { outside the bodies of susceptible hosts } \\
\text { (i.e. in the abiotic environment) }\end{array}$ & 1 \\
\hline $\begin{array}{l}\text { Amenability of vaccine to large-scale } \\
\text { application (including cold-chain } \\
\text { requirement) }\end{array}$ & 4 & $\begin{array}{l}\text { Availability of laboratory tests for } \\
\text { reliable identification of the infection } \\
\text { in dead animals }\end{array}$ & 4 & Multiplicity of livestock hosts & 1 \\
\hline $\begin{array}{l}\text { Safety/innocuity of vaccine } \\
\text { (acceptability to livestock owners) }\end{array}$ & 4 & $\begin{array}{l}\text { Availability of tests to differentiate } \\
\text { antibody responses to infection vs } \\
\text { vaccination (DIVA) }\end{array}$ & 2 & $\begin{array}{l}\text { Importance of free-living wildlife in } \\
\text { maintenance } \& \text { transmission of the } \\
\text { infection }\end{array}$ & 3 \\
\hline \multirow[t]{3}{*}{$\begin{array}{l}\text { Cost of vaccine } \& \text { vaccine } \\
\text { administration }\end{array}$} & 4 & $\begin{array}{l}\text { Availability of rapid testing systems } \\
\text { (e.g. pen-side tests) }\end{array}$ & 1 & $\begin{array}{l}\text { Extent of biological variation, including } \\
\text { antigenic variation, within the } \\
\text { infectious agent population }\end{array}$ & 4 \\
\hline & & & & $\begin{array}{l}\text { Ability of recovered animals to } \\
\text { transmit the infection (e.g. carrier } \\
\text { transmission) }\end{array}$ & 5 \\
\hline & & & & $\begin{array}{l}\text { Level of immunity \& duration in } \\
\text { recovered vertebrates }\end{array}$ & 4 \\
\hline
\end{tabular}




\section{Classical swine fever}

\begin{tabular}{|c|c|c|c|c|c|}
\hline Disease management efficacy & Score & Surveillance factors & Score & Epidemiological factors & Score \\
\hline $\begin{array}{l}\text { Induction of solid immunity to } \\
\text { infection by available vaccine }\end{array}$ & 4 & $\begin{array}{l}\text { Clinical signs in domestic livestock } \\
\text { host(s) characteristic }\end{array}$ & 2 & $\begin{array}{l}\text { Persistence in \& transmission of the } \\
\text { agent by invertebrate vectors }\end{array}$ & 5 \\
\hline $\begin{array}{l}\text { Duration of vaccinal immunity/ } \\
\text { requirement for administration of } \\
\text { multiple (booster) vaccinations }\end{array}$ & 4 & $\begin{array}{l}\text { Availability of laboratory tests for } \\
\text { reliable identification of the infection } \\
\text { in live animals }\end{array}$ & 2 & $\begin{array}{l}\text { Persistence/multiplication of the agent } \\
\text { outside the bodies of susceptible hosts } \\
\text { (i.e. in the abiotic environment) }\end{array}$ & 4 \\
\hline $\begin{array}{l}\text { Amenability of vaccine to large-scale } \\
\text { application (including cold-chain } \\
\text { requirement) }\end{array}$ & 4 & $\begin{array}{l}\text { Availability of laboratory tests for } \\
\text { reliable identification of the infection } \\
\text { in dead animals }\end{array}$ & 5 & Multiplicity of livestock hosts & 5 \\
\hline $\begin{array}{l}\text { Safety/innocuity of vaccine } \\
\text { (acceptability to livestock owners) }\end{array}$ & 4 & $\begin{array}{l}\text { Availability of tests to differentiate } \\
\text { antibody responses to infection vs } \\
\text { vaccination (DIVA) }\end{array}$ & 3 & $\begin{array}{l}\text { Importance of free-living wildlife in } \\
\text { maintenance \& transmission of the } \\
\text { infection }\end{array}$ & 3 \\
\hline \multirow[t]{3}{*}{$\begin{array}{l}\text { Cost of vaccine } \& \text { vaccine } \\
\text { administration }\end{array}$} & 3 & $\begin{array}{l}\text { Availability of rapid testing systems } \\
\text { (e.g. pen-side tests) }\end{array}$ & 2 & $\begin{array}{l}\text { Extent of biological variation, including } \\
\text { antigenic variation, within the } \\
\text { infectious agent population }\end{array}$ & 4 \\
\hline & & & & $\begin{array}{l}\text { Ability of recovered animals to } \\
\text { transmit the infection (e.g. carrier } \\
\text { transmission) }\end{array}$ & 4 \\
\hline & & & & $\begin{array}{l}\text { Level of immunity \& duration in } \\
\text { recovered vertebrates }\end{array}$ & 4 \\
\hline
\end{tabular}




\section{Blue tongue}

\begin{tabular}{|c|c|c|c|c|c|}
\hline Disease management efficacy & Score & Surveillance factors & Score & Epidemiological factors & Score \\
\hline $\begin{array}{l}\text { Induction of solid immunity to } \\
\text { infection by available vaccine }\end{array}$ & 4 & $\begin{array}{l}\text { Clinical signs in domestic livestock } \\
\text { host(s) characteristic }\end{array}$ & 3 & $\begin{array}{l}\text { Persistence in \& transmission of the } \\
\text { agent by invertebrate vectors }\end{array}$ & 1 \\
\hline $\begin{array}{l}\text { Duration of vaccinal immunity/ } \\
\text { requirement for administration of } \\
\text { multiple (booster) vaccinations }\end{array}$ & 3 & $\begin{array}{l}\text { Availability of laboratory tests for } \\
\text { reliable identification of the infection } \\
\text { in live animals }\end{array}$ & 2 & $\begin{array}{l}\text { Persistence/multiplication of the agent } \\
\text { outside the bodies of susceptible hosts } \\
\text { (i.e. in the abiotic environment) }\end{array}$ & 5 \\
\hline $\begin{array}{l}\text { Amenability of vaccine to large-scale } \\
\text { application (including cold-chain } \\
\text { requirement) }\end{array}$ & 2 & $\begin{array}{l}\text { Availability of laboratory tests for } \\
\text { reliable identification of the infection } \\
\text { in dead animals }\end{array}$ & 5 & Multiplicity of livestock hosts & 3 \\
\hline $\begin{array}{l}\text { Safety/innocuity of vaccine } \\
\text { (acceptability to livestock owners) }\end{array}$ & 3 & $\begin{array}{l}\text { Availability of tests to differentiate } \\
\text { antibody responses to infection vs } \\
\text { vaccination (DIVA) }\end{array}$ & 1 & $\begin{array}{l}\text { Importance of free-living wildlife in } \\
\text { maintenance \& transmission of the } \\
\text { infection }\end{array}$ & 3 \\
\hline \multirow[t]{3}{*}{$\begin{array}{l}\text { Cost of vaccine } \& \text { vaccine } \\
\text { administration }\end{array}$} & 4 & $\begin{array}{l}\text { Availability of rapid testing systems } \\
\text { (e.g. pen-side tests) }\end{array}$ & 1 & $\begin{array}{l}\text { Extent of biological variation, including } \\
\text { antigenic variation, within the } \\
\text { infectious agent population }\end{array}$ & 2 \\
\hline & & & & $\begin{array}{l}\text { Ability of recovered animals to } \\
\text { transmit the infection (e.g. carrier } \\
\text { transmission) }\end{array}$ & 5 \\
\hline & & & & $\begin{array}{l}\text { Level of immunity } \& \text { duration in } \\
\text { recovered vertebrates }\end{array}$ & 4 \\
\hline
\end{tabular}


Peste des petits ruminants

\begin{tabular}{|c|c|c|c|c|c|}
\hline Disease management efficacy & Score & Surveillance factors & Score & Epidemiological factors & Score \\
\hline $\begin{array}{l}\text { Induction of solid immunity to } \\
\text { infection by available vaccine }\end{array}$ & 4 & $\begin{array}{l}\text { Clinical signs in domestic livestock } \\
\text { host(s) characteristic }\end{array}$ & 3 & $\begin{array}{l}\text { Persistence in \& transmission of the } \\
\text { agent by invertebrate vectors }\end{array}$ & 5 \\
\hline $\begin{array}{l}\text { Duration of vaccinal immunity/ } \\
\text { requirement for administration of } \\
\text { multiple (booster) vaccinations }\end{array}$ & 4 & $\begin{array}{l}\text { Availability of laboratory tests for } \\
\text { reliable identification of the infection } \\
\text { in live animals }\end{array}$ & 3 & $\begin{array}{l}\text { Persistence/multiplication of the agent } \\
\text { outside the bodies of susceptible hosts } \\
\text { (i.e. in the abiotic environment) }\end{array}$ & 5 \\
\hline $\begin{array}{l}\text { Amenability of vaccine to large-scale } \\
\text { application (including cold-chain } \\
\text { requirement) }\end{array}$ & 3 & $\begin{array}{l}\text { Availability of laboratory tests for } \\
\text { reliable identification of the infection } \\
\text { in dead animals }\end{array}$ & 5 & Multiplicity of livestock hosts & 4 \\
\hline $\begin{array}{l}\text { Safety/innocuity of vaccine } \\
\text { (acceptability to livestock owners) }\end{array}$ & 3 & $\begin{array}{l}\text { Availability of tests to differentiate } \\
\text { antibody responses to infection vs } \\
\text { vaccination (DIVA) }\end{array}$ & 1 & $\begin{array}{l}\text { Importance of free-living wildlife in } \\
\text { maintenance \& transmission of the } \\
\text { infection }\end{array}$ & 3 \\
\hline \multirow[t]{3}{*}{$\begin{array}{l}\text { Cost of vaccine } \& \text { vaccine } \\
\text { administration }\end{array}$} & 3 & $\begin{array}{l}\text { Availability of rapid testing systems } \\
\text { (e.g. pen-side tests) }\end{array}$ & 3 & $\begin{array}{l}\text { Extent of biological variation, including } \\
\text { antigenic variation, within the } \\
\text { infectious agent population }\end{array}$ & 5 \\
\hline & & & & $\begin{array}{l}\text { Ability of recovered animals to } \\
\text { transmit the infection (e.g. carrier } \\
\text { transmission) }\end{array}$ & 5 \\
\hline & & & & $\begin{array}{l}\text { Level of immunity \& duration in } \\
\text { recovered vertebrates }\end{array}$ & 5 \\
\hline
\end{tabular}




\section{Bovine tuberculosis}

\begin{tabular}{|c|c|c|c|c|c|}
\hline Disease management efficacy & Score & Surveillance factors & Score & Epidemiological factors & Score \\
\hline $\begin{array}{l}\text { Induction of solid immunity to } \\
\text { infection by available vaccine }\end{array}$ & 4 & $\begin{array}{l}\text { Clinical signs in domestic livestock } \\
\text { host(s) characteristic }\end{array}$ & 2 & $\begin{array}{l}\text { Persistence in \& transmission of the } \\
\text { agent by invertebrate vectors }\end{array}$ & 5 \\
\hline $\begin{array}{l}\text { Duration of vaccinal immunity/ } \\
\text { requirement for administration of } \\
\text { multiple (booster) vaccinations }\end{array}$ & 5 & $\begin{array}{l}\text { Availability of laboratory tests for } \\
\text { reliable identification of the infection } \\
\text { in live animals }\end{array}$ & 3 & $\begin{array}{l}\text { Persistence/multiplication of the agent } \\
\text { outside the bodies of susceptible hosts } \\
\text { (i.e. in the abiotic environment) }\end{array}$ & 3 \\
\hline $\begin{array}{l}\text { Amenability of vaccine to large-scale } \\
\text { application (including cold-chain } \\
\text { requirement) }\end{array}$ & 2 & $\begin{array}{l}\text { Availability of laboratory tests for } \\
\text { reliable identification of the infection } \\
\text { in dead animals }\end{array}$ & 4 & Multiplicity of livestock hosts & 2 \\
\hline $\begin{array}{l}\text { Safety/innocuity of vaccine } \\
\text { (acceptability to livestock owners) }\end{array}$ & 3 & $\begin{array}{l}\text { Availability of tests to differentiate } \\
\text { antibody responses to infection vs } \\
\text { vaccination (DIVA) }\end{array}$ & 1 & $\begin{array}{l}\text { Importance of free-living wildlife in } \\
\text { maintenance \& transmission of the } \\
\text { infection }\end{array}$ & 3 \\
\hline \multirow[t]{3}{*}{$\begin{array}{l}\text { Cost of vaccine } \& \text { vaccine } \\
\text { administration }\end{array}$} & 4 & $\begin{array}{l}\text { Availability of rapid testing systems } \\
\text { (e.g. pen-side tests) }\end{array}$ & 3 & $\begin{array}{l}\text { Extent of biological variation, including } \\
\text { antigenic variation, within the } \\
\text { infectious agent population }\end{array}$ & 4 \\
\hline & & & & $\begin{array}{l}\text { Ability of recovered animals to } \\
\text { transmit the infection (e.g. carrier } \\
\text { transmission) }\end{array}$ & 1 \\
\hline & & & & $\begin{array}{l}\text { Level of immunity \& duration in } \\
\text { recovered vertebrates }\end{array}$ & 4 \\
\hline
\end{tabular}




\begin{tabular}{|c|c|c|c|c|c|}
\hline Disease management efficacy & Score & Surveillance factors & Score & Epidemiological factors & Score \\
\hline $\begin{array}{l}\text { Induction of solid immunity to } \\
\text { infection by available vaccine }\end{array}$ & 4 & $\begin{array}{l}\text { Clinical signs in domestic livestock } \\
\text { host(s) characteristic }\end{array}$ & 2 & $\begin{array}{l}\text { Persistence in \& transmission of the } \\
\text { agent by invertebrate vectors }\end{array}$ & 5 \\
\hline $\begin{array}{l}\text { Duration of vaccinal immunity/ } \\
\text { requirement for administration of } \\
\text { multiple (booster) vaccinations }\end{array}$ & 3 & $\begin{array}{l}\text { Availability of laboratory tests for } \\
\text { reliable identification of the infection } \\
\text { in live animals }\end{array}$ & 2 & $\begin{array}{l}\text { Persistence/multiplication of the agent } \\
\text { outside the bodies of susceptible hosts } \\
\text { (i.e. in the abiotic environment) }\end{array}$ & 5 \\
\hline $\begin{array}{l}\text { Amenability of vaccine to large-scale } \\
\text { application (including cold-chain } \\
\text { requirement) }\end{array}$ & 3 & $\begin{array}{l}\text { Availability of laboratory tests for } \\
\text { reliable identification of the infection } \\
\text { in dead animals }\end{array}$ & 4 & Multiplicity of livestock hosts & 5 \\
\hline $\begin{array}{l}\text { Safety/innocuity of vaccine } \\
\text { (acceptability to livestock owners) }\end{array}$ & 2 & $\begin{array}{l}\text { Availability of tests to differentiate } \\
\text { antibody responses to infection vs } \\
\text { vaccination (DIVA) }\end{array}$ & 1 & $\begin{array}{l}\text { Importance of free-living wildlife in } \\
\text { maintenance \& transmission of the } \\
\text { infection }\end{array}$ & 5 \\
\hline \multirow[t]{3}{*}{$\begin{array}{l}\text { Cost of vaccine } \& \text { vaccine } \\
\text { administration }\end{array}$} & 3 & $\begin{array}{l}\text { Availability of rapid testing systems } \\
\text { (e.g. pen-side tests) }\end{array}$ & 1 & $\begin{array}{l}\text { Extent of biological variation, including } \\
\text { antigenic variation, within the } \\
\text { infectious agent population }\end{array}$ & 3 \\
\hline & & & & $\begin{array}{l}\text { Ability of recovered animals to } \\
\text { transmit the infection (e.g. carrier } \\
\text { transmission) }\end{array}$ & 3 \\
\hline & & & & $\begin{array}{l}\text { Level of immunity \& duration in } \\
\text { recovered vertebrates }\end{array}$ & 3 \\
\hline
\end{tabular}


Caprine brucellosis (Br. Melitensis)

\begin{tabular}{|l|c|l|c|l|}
\hline \multicolumn{1}{|c|}{ Disease management efficacy } & Score & \multicolumn{1}{|c|}{ Surveillance factors } & Score & Epidemiological factors \\
\hline $\begin{array}{l}\text { Induction of solid immunity to } \\
\text { infection by available vaccine }\end{array}$ & 4 & $\begin{array}{l}\text { Clinical signs in domestic livestock } \\
\text { host(s) characteristic }\end{array}$ & 2 & $\begin{array}{l}\text { Persistence in \& transmission of the } \\
\text { agent by invertebrate vectors }\end{array}$ \\
\hline $\begin{array}{l}\text { Duration of vaccinal immunity/ } \\
\text { requirement for administration of } \\
\text { multiple (booster) vaccinations }\end{array}$ & 5 & $\begin{array}{l}\text { Availability of laboratory tests for } \\
\text { reliable identification of the infection } \\
\text { in live animals }\end{array}$ & 1 & $\begin{array}{l}\text { Persistence/multiplication of the agent } \\
\text { outside the bodies of susceptible hosts } \\
\text { (i.e. in the abiotic environment) }\end{array}$ \\
\hline $\begin{array}{l}\text { Amenability of vaccine to large-scale } \\
\text { application (including cold-chain } \\
\text { requirement) }\end{array}$ & 2 & $\begin{array}{l}\text { Availability of laboratory tests for } \\
\text { reliable identification of the infection } \\
\text { in dead animals }\end{array}$ & 4 & Multiplicity of livestock hosts \\
\hline $\begin{array}{l}\text { Safety/innocuity of vaccine } \\
\text { (acceptability to livestock owners) }\end{array}$ & 2 & $\begin{array}{l}\text { Availability of tests to differentiate } \\
\text { antibody responses to infection vs } \\
\text { vaccination (DIVA) }\end{array}$ & 1 & $\begin{array}{l}\text { Importance of free-living wildlife in } \\
\text { maintenance \& transmission of the } \\
\text { infection }\end{array}$ \\
\hline $\begin{array}{l}\text { Cost of vaccine \& vaccine } \\
\text { administration }\end{array}$ & 4 & $\begin{array}{l}\text { Availability of rapid testing systems } \\
\text { (e.g. pen-side tests) }\end{array}$ & 2 & $\begin{array}{l}\text { Extent of biological variation, including } \\
\text { antigenic variation, within the } \\
\text { infectious agent population }\end{array}$ \\
\hline & & & $\begin{array}{l}\text { Ability of recovered animals to } \\
\text { transmit the infection (e.g. carrier } \\
\text { transmission) }\end{array}$ \\
\hline
\end{tabular}


Equine herpesvirus 1

\begin{tabular}{|c|c|c|c|c|c|}
\hline Disease management efficacy & Score & Surveillance factors & Score & Epidemiological factors & Score \\
\hline $\begin{array}{l}\text { Induction of solid immunity to } \\
\text { infection by available vaccine }\end{array}$ & 3 & $\begin{array}{l}\text { Clinical signs in domestic livestock } \\
\text { host(s) characteristic }\end{array}$ & 2 & $\begin{array}{l}\text { Persistence in \& transmission of the } \\
\text { agent by invertebrate vectors }\end{array}$ & 5 \\
\hline $\begin{array}{l}\text { Duration of vaccinal immunity/ } \\
\text { requirement for administration of } \\
\text { multiple (booster) vaccinations }\end{array}$ & 1 & $\begin{array}{l}\text { Availability of laboratory tests for } \\
\text { reliable identification of the infection } \\
\text { in live animals }\end{array}$ & 1 & $\begin{array}{l}\text { Persistence/multiplication of the agent } \\
\text { outside the bodies of susceptible hosts } \\
\text { (i.e. in the abiotic environment) }\end{array}$ & 5 \\
\hline $\begin{array}{l}\text { Amenability of vaccine to large-scale } \\
\text { application (including cold-chain } \\
\text { requirement) }\end{array}$ & 2 & $\begin{array}{l}\text { Availability of laboratory tests for } \\
\text { reliable identification of the infection } \\
\text { in dead animals }\end{array}$ & 4 & Multiplicity of livestock hosts & 5 \\
\hline $\begin{array}{l}\text { Safety/innocuity of vaccine } \\
\text { (acceptability to livestock owners) }\end{array}$ & 4 & $\begin{array}{l}\text { Availability of tests to differentiate } \\
\text { antibody responses to infection vs } \\
\text { vaccination (DIVA) }\end{array}$ & 1 & $\begin{array}{l}\text { Importance of free-living wildlife in } \\
\text { maintenance \& transmission of the } \\
\text { infection }\end{array}$ & 5 \\
\hline \multirow[t]{3}{*}{$\begin{array}{l}\text { Cost of vaccine } \& \text { vaccine } \\
\text { administration }\end{array}$} & 3 & $\begin{array}{l}\text { Availability of rapid testing systems } \\
\text { (e.g. pen-side tests) }\end{array}$ & 1 & $\begin{array}{l}\text { Extent of biological variation, including } \\
\text { antigenic variation, within the } \\
\text { infectious agent population }\end{array}$ & 3 \\
\hline & & & & $\begin{array}{l}\text { Ability of recovered animals to } \\
\text { transmit the infection (e.g. carrier } \\
\text { transmission) }\end{array}$ & 1 \\
\hline & & & & $\begin{array}{l}\text { Level of immunity \& duration in } \\
\text { recovered vertebrates }\end{array}$ & 3 \\
\hline
\end{tabular}


Foot and mouth disease - SAT serotypes

\begin{tabular}{|c|c|c|c|c|c|}
\hline Disease management efficacy & Score & Surveillance factors & Score & Epidemiological factors & Score \\
\hline $\begin{array}{l}\text { Induction of solid immunity to } \\
\text { infection by available vaccine }\end{array}$ & 2 & $\begin{array}{l}\text { Clinical signs in domestic livestock } \\
\text { host(s) characteristic }\end{array}$ & 4 & $\begin{array}{l}\text { Persistence in \& transmission of the } \\
\text { agent by invertebrate vectors }\end{array}$ & 5 \\
\hline $\begin{array}{l}\text { Duration of vaccinal immunity/ } \\
\text { requirement for administration of } \\
\text { multiple (booster) vaccinations }\end{array}$ & 2 & $\begin{array}{l}\text { Availability of laboratory tests for } \\
\text { reliable identification of the infection } \\
\text { in live animals }\end{array}$ & 5 & $\begin{array}{l}\text { Persistence/multiplication of the agent } \\
\text { outside the bodies of susceptible hosts } \\
\text { (i.e. in the abiotic environment) }\end{array}$ & 4 \\
\hline $\begin{array}{l}\text { Amenability of vaccine to large-scale } \\
\text { application (including cold-chain } \\
\text { requirement) }\end{array}$ & 3 & $\begin{array}{l}\text { Availability of laboratory tests for } \\
\text { reliable identification of the infection } \\
\text { in dead animals }\end{array}$ & 4 & Multiplicity of livestock hosts & 2 \\
\hline $\begin{array}{l}\text { Safety/innocuity of vaccine } \\
\text { (acceptability to livestock owners) }\end{array}$ & 5 & $\begin{array}{l}\text { Availability of tests to differentiate } \\
\text { antibody responses to infection vs } \\
\text { vaccination (DIVA) }\end{array}$ & 3 & $\begin{array}{l}\text { Importance of free-living wildlife in } \\
\text { maintenance \& transmission of the } \\
\text { infection }\end{array}$ & 1 \\
\hline \multirow[t]{3}{*}{$\begin{array}{l}\text { Cost of vaccine } \& \text { vaccine } \\
\text { administration }\end{array}$} & 3 & $\begin{array}{l}\text { Availability of rapid testing systems } \\
\text { (e.g. pen-side tests) }\end{array}$ & 1 & $\begin{array}{l}\text { Extent of biological variation, including } \\
\text { antigenic variation, within the } \\
\text { infectious agent population }\end{array}$ & 1 \\
\hline & & & & $\begin{array}{l}\text { Ability of recovered animals to } \\
\text { transmit the infection (e.g. carrier } \\
\text { transmission) }\end{array}$ & 2 \\
\hline & & & & $\begin{array}{l}\text { Level of immunity \& duration in } \\
\text { recovered vertebrates }\end{array}$ & 3 \\
\hline
\end{tabular}




\begin{tabular}{|c|c|c|c|c|c|}
\hline Disease management efficacy & Score & Surveillance factors & Score & Epidemiological factors & Score \\
\hline $\begin{array}{l}\text { Induction of solid immunity to } \\
\text { infection by available vaccine }\end{array}$ & 4 & $\begin{array}{l}\text { Clinical signs in domestic livestock } \\
\text { host(s) characteristic }\end{array}$ & 3 & $\begin{array}{l}\text { Persistence in \& transmission of the } \\
\text { agent by invertebrate vectors }\end{array}$ & 5 \\
\hline $\begin{array}{l}\text { Duration of vaccinal immunity/ } \\
\text { requirement for administration of } \\
\text { multiple (booster) vaccinations }\end{array}$ & 2 & $\begin{array}{l}\text { Availability of laboratory tests for } \\
\text { reliable identification of the infection } \\
\text { in live animals }\end{array}$ & 4 & $\begin{array}{l}\text { Persistence/multiplication of the agent } \\
\text { outside the bodies of susceptible hosts } \\
\text { (i.e. in the abiotic environment) }\end{array}$ & 5 \\
\hline $\begin{array}{l}\text { Amenability of vaccine to large-scale } \\
\text { application (including cold-chain } \\
\text { requirement) }\end{array}$ & 3 & $\begin{array}{l}\text { Availability of laboratory tests for } \\
\text { reliable identification of the infection } \\
\text { in dead animals }\end{array}$ & 3 & Multiplicity of livestock hosts & 4 \\
\hline $\begin{array}{l}\text { Safety/innocuity of vaccine } \\
\text { (acceptability to livestock owners) }\end{array}$ & 5 & $\begin{array}{l}\text { Availability of tests to differentiate } \\
\text { antibody responses to infection vs } \\
\text { vaccination (DIVA) }\end{array}$ & 1 & $\begin{array}{l}\text { Importance of free-living wildlife in } \\
\text { maintenance \& transmission of the } \\
\text { infection }\end{array}$ & 5 \\
\hline \multirow[t]{3}{*}{$\begin{array}{l}\text { Cost of vaccine } \& \text { vaccine } \\
\text { administration }\end{array}$} & 3 & $\begin{array}{l}\text { Availability of rapid testing systems } \\
\text { (e.g. pen-side tests) }\end{array}$ & 1 & $\begin{array}{l}\text { Extent of biological variation, including } \\
\text { antigenic variation, within the } \\
\text { infectious agent population }\end{array}$ & 2 \\
\hline & & & & $\begin{array}{l}\text { Ability of recovered animals to } \\
\text { transmit the infection (e.g. carrier } \\
\text { transmission) }\end{array}$ & 5 \\
\hline & & & & $\begin{array}{l}\text { Level of immunity \& duration in } \\
\text { recovered vertebrates }\end{array}$ & 3 \\
\hline
\end{tabular}


Foot and mouth disease - Eurasian serotypes

\begin{tabular}{|c|c|c|c|c|c|}
\hline Disease management efficacy & Score & Surveillance factors & Score & Epidemiological factors & Score \\
\hline $\begin{array}{l}\text { Induction of solid immunity to } \\
\text { infection by available vaccine }\end{array}$ & 3 & $\begin{array}{l}\text { Clinical signs in domestic livestock } \\
\text { host(s) characteristic }\end{array}$ & 4 & $\begin{array}{l}\text { Persistence in \& transmission of the } \\
\text { agent by invertebrate vectors }\end{array}$ & 5 \\
\hline $\begin{array}{l}\text { Duration of vaccinal immunity/ } \\
\text { requirement for administration of } \\
\text { multiple (booster) vaccinations }\end{array}$ & 3 & $\begin{array}{l}\text { Availability of laboratory tests for } \\
\text { reliable identification of the infection } \\
\text { in live animals }\end{array}$ & 5 & $\begin{array}{l}\text { Persistence/multiplication of the agent } \\
\text { outside the bodies of susceptible hosts } \\
\text { (i.e. in the abiotic environment) }\end{array}$ & 4 \\
\hline $\begin{array}{l}\text { Amenability of vaccine to large-scale } \\
\text { application (including cold-chain } \\
\text { requirement) }\end{array}$ & 3 & $\begin{array}{l}\text { Availability of laboratory tests for } \\
\text { reliable identification of the infection } \\
\text { in dead animals }\end{array}$ & 4 & Multiplicity of livestock hosts & 2 \\
\hline $\begin{array}{l}\text { Safety/innocuity of vaccine } \\
\text { (acceptability to livestock owners) }\end{array}$ & 5 & $\begin{array}{l}\text { Availability of tests to differentiate } \\
\text { antibody responses to infection vs } \\
\text { vaccination (DIVA) }\end{array}$ & 5 & $\begin{array}{l}\text { Importance of free-living wildlife in } \\
\text { maintenance \& transmission of the } \\
\text { infection }\end{array}$ & 4 \\
\hline \multirow[t]{3}{*}{$\begin{array}{l}\text { Cost of vaccine } \& \text { vaccine } \\
\text { administration }\end{array}$} & 3 & $\begin{array}{l}\text { Availability of rapid testing systems } \\
\text { (e.g. pen-side tests) }\end{array}$ & 4 & $\begin{array}{l}\text { Extent of biological variation, including } \\
\text { antigenic variation, within the } \\
\text { infectious agent population }\end{array}$ & 3 \\
\hline & & & & $\begin{array}{l}\text { Ability of recovered animals to } \\
\text { transmit the infection (e.g. carrier } \\
\text { transmission) }\end{array}$ & 4 \\
\hline & & & & $\begin{array}{l}\text { Level of immunity \& duration in } \\
\text { recovered vertebrates }\end{array}$ & 3 \\
\hline
\end{tabular}




\section{African horse sickness}

\begin{tabular}{|c|c|c|c|c|c|}
\hline Disease management efficacy & Score & Surveillance factors & Score & Epidemiological factors & Score \\
\hline $\begin{array}{l}\text { Induction of solid immunity to } \\
\text { infection by available vaccine }\end{array}$ & 3 & $\begin{array}{l}\text { Clinical signs in domestic livestock } \\
\text { host(s) characteristic }\end{array}$ & 3 & $\begin{array}{l}\text { Persistence in \& transmission of the } \\
\text { agent by invertebrate vectors }\end{array}$ & 1 \\
\hline $\begin{array}{l}\text { Duration of vaccinal immunity/ } \\
\text { requirement for administration of } \\
\text { multiple (booster) vaccinations }\end{array}$ & 3 & $\begin{array}{l}\text { Availability of laboratory tests for } \\
\text { reliable identification of the infection } \\
\text { in live animals }\end{array}$ & 1 & $\begin{array}{l}\text { Persistence/multiplication of the agent } \\
\text { outside the bodies of susceptible hosts } \\
\text { (i.e. in the abiotic environment) }\end{array}$ & 4 \\
\hline $\begin{array}{l}\text { Amenability of vaccine to large-scale } \\
\text { application (including cold-chain } \\
\text { requirement) }\end{array}$ & 3 & $\begin{array}{l}\text { Availability of laboratory tests for } \\
\text { reliable identification of the infection } \\
\text { in dead animals }\end{array}$ & 5 & Multiplicity of livestock hosts & 4 \\
\hline $\begin{array}{l}\text { Safety/innocuity of vaccine } \\
\text { (acceptability to livestock owners) }\end{array}$ & 3 & $\begin{array}{l}\text { Availability of tests to differentiate } \\
\text { antibody responses to infection vs } \\
\text { vaccination (DIVA) }\end{array}$ & 1 & $\begin{array}{l}\text { Importance of free-living wildlife in } \\
\text { maintenance \& transmission of the } \\
\text { infection }\end{array}$ & 2 \\
\hline \multirow[t]{3}{*}{$\begin{array}{l}\text { Cost of vaccine } \& \text { vaccine } \\
\text { administration }\end{array}$} & 2 & $\begin{array}{l}\text { Availability of rapid testing systems } \\
\text { (e.g. pen-side tests) }\end{array}$ & 1 & $\begin{array}{l}\text { Extent of biological variation, including } \\
\text { antigenic variation, within the } \\
\text { infectious agent population }\end{array}$ & 2 \\
\hline & & & & $\begin{array}{l}\text { Ability of recovered animals to } \\
\text { transmit the infection (e.g. carrier } \\
\text { transmission) }\end{array}$ & 5 \\
\hline & & & & $\begin{array}{l}\text { Level of immunity \& duration in } \\
\text { recovered vertebrates }\end{array}$ & 5 \\
\hline
\end{tabular}




\section{Heartwater}

\begin{tabular}{|c|c|c|c|c|c|}
\hline Disease management efficacy & Score & Surveillance factors & Score & Epidemiological factors & Score \\
\hline $\begin{array}{l}\text { Induction of solid immunity to } \\
\text { infection by available vaccine }\end{array}$ & 4 & $\begin{array}{l}\text { Clinical signs in domestic livestock } \\
\text { host(s) characteristic }\end{array}$ & 3 & $\begin{array}{l}\text { Persistence in \& transmission of the } \\
\text { agent by invertebrate vectors }\end{array}$ & 1 \\
\hline $\begin{array}{l}\text { Duration of vaccinal immunity/ } \\
\text { requirement for administration of } \\
\text { multiple (booster) vaccinations }\end{array}$ & 5 & $\begin{array}{l}\text { Availability of laboratory tests for } \\
\text { reliable identification of the infection } \\
\text { in live animals }\end{array}$ & 2 & $\begin{array}{l}\text { Persistence/multiplication of the agent } \\
\text { outside the bodies of susceptible hosts } \\
\text { (i.e. in the abiotic environment) }\end{array}$ & 5 \\
\hline $\begin{array}{l}\text { Amenability of vaccine to large-scale } \\
\text { application (including cold-chain } \\
\text { requirement) }\end{array}$ & 1 & $\begin{array}{l}\text { Availability of laboratory tests for } \\
\text { reliable identification of the infection } \\
\text { in dead animals }\end{array}$ & 5 & Multiplicity of livestock hosts & 3 \\
\hline $\begin{array}{l}\text { Safety/innocuity of vaccine } \\
\text { (acceptability to livestock owners) }\end{array}$ & 2 & $\begin{array}{l}\text { Availability of tests to differentiate } \\
\text { antibody responses to infection vs } \\
\text { vaccination (DIVA) }\end{array}$ & 1 & $\begin{array}{l}\text { Importance of free-living wildlife in } \\
\text { maintenance \& transmission of the } \\
\text { infection }\end{array}$ & 3 \\
\hline \multirow[t]{3}{*}{$\begin{array}{l}\text { Cost of vaccine } \& \text { vaccine } \\
\text { administration }\end{array}$} & 3 & $\begin{array}{l}\text { Availability of rapid testing systems } \\
\text { (e.g. pen-side tests) }\end{array}$ & 1 & $\begin{array}{l}\text { Extent of biological variation, including } \\
\text { antigenic variation, within the } \\
\text { infectious agent population }\end{array}$ & 2 \\
\hline & & & & $\begin{array}{l}\text { Ability of recovered animals to } \\
\text { transmit the infection (e.g. carrier } \\
\text { transmission) }\end{array}$ & 2 \\
\hline & & & & $\begin{array}{l}\text { Level of immunity \& duration in } \\
\text { recovered vertebrates }\end{array}$ & 4 \\
\hline
\end{tabular}


Contagious bovine pleuropneumonia

\begin{tabular}{|c|c|c|c|c|c|}
\hline Disease management efficacy & Score & Surveillance factors & Score & Epidemiological factors & Score \\
\hline $\begin{array}{l}\text { Induction of solid immunity to } \\
\text { infection by available vaccine }\end{array}$ & 3 & $\begin{array}{l}\text { Clinical signs in domestic livestock } \\
\text { host(s) characteristic }\end{array}$ & 3 & $\begin{array}{l}\text { Persistence in \& transmission of the } \\
\text { agent by invertebrate vectors }\end{array}$ & 5 \\
\hline $\begin{array}{l}\text { Duration of vaccinal immunity/ } \\
\text { requirement for administration of } \\
\text { multiple (booster) vaccinations }\end{array}$ & 3 & $\begin{array}{l}\text { Availability of laboratory tests for } \\
\text { reliable identification of the infection } \\
\text { in live animals }\end{array}$ & 1 & $\begin{array}{l}\text { Persistence/multiplication of the agent } \\
\text { outside the bodies of susceptible hosts } \\
\text { (i.e. in the abiotic environment) }\end{array}$ & 5 \\
\hline $\begin{array}{l}\text { Amenability of vaccine to large-scale } \\
\text { application (including cold-chain } \\
\text { requirement) }\end{array}$ & 3 & $\begin{array}{l}\text { Availability of laboratory tests for } \\
\text { reliable identification of the infection } \\
\text { in dead animals }\end{array}$ & 4 & Multiplicity of livestock hosts & 5 \\
\hline $\begin{array}{l}\text { Safety/innocuity of vaccine } \\
\text { (acceptability to livestock owners) }\end{array}$ & 3 & $\begin{array}{l}\text { Availability of tests to differentiate } \\
\text { antibody responses to infection vs } \\
\text { vaccination (DIVA) }\end{array}$ & 1 & $\begin{array}{l}\text { Importance of free-living wildlife in } \\
\text { maintenance \& transmission of the } \\
\text { infection }\end{array}$ & 5 \\
\hline \multirow[t]{3}{*}{$\begin{array}{l}\text { Cost of vaccine } \& \text { vaccine } \\
\text { administration }\end{array}$} & 4 & $\begin{array}{l}\text { Availability of rapid testing systems } \\
\text { (e.g. pen-side tests) }\end{array}$ & 1 & $\begin{array}{l}\text { Extent of biological variation, including } \\
\text { antigenic variation, within the } \\
\text { infectious agent population }\end{array}$ & 5 \\
\hline & & & & $\begin{array}{l}\text { Ability of recovered animals to } \\
\text { transmit the infection (e.g. carrier } \\
\text { transmission) }\end{array}$ & 4 \\
\hline & & & & $\begin{array}{l}\text { Level of immunity \& duration in } \\
\text { recovered vertebrates }\end{array}$ & 4 \\
\hline
\end{tabular}




\section{Paratuberculosis}

\begin{tabular}{|c|c|c|c|c|c|}
\hline Disease management efficacy & Score & Surveillance factors & Score & Epidemiological factors & Score \\
\hline $\begin{array}{l}\text { Induction of solid immunity to } \\
\text { infection by available vaccine }\end{array}$ & 1 & $\begin{array}{l}\text { Clinical signs in domestic livestock } \\
\text { host(s) characteristic }\end{array}$ & 3 & $\begin{array}{l}\text { Persistence in \& transmission of the } \\
\text { agent by invertebrate vectors }\end{array}$ & 5 \\
\hline $\begin{array}{l}\text { Duration of vaccinal immunity/ } \\
\text { requirement for administration of } \\
\text { multiple (booster) vaccinations }\end{array}$ & 2 & $\begin{array}{l}\text { Availability of laboratory tests for } \\
\text { reliable identification of the infection } \\
\text { in live animals }\end{array}$ & 2 & $\begin{array}{l}\text { Persistence/multiplication of the agent } \\
\text { outside the bodies of susceptible hosts } \\
\text { (i.e. in the abiotic environment) }\end{array}$ & 2 \\
\hline $\begin{array}{l}\text { Amenability of vaccine to large-scale } \\
\text { application (including cold-chain } \\
\text { requirement) }\end{array}$ & 2 & $\begin{array}{l}\text { Availability of laboratory tests for } \\
\text { reliable identification of the infection } \\
\text { in dead animals }\end{array}$ & 4 & Multiplicity of livestock hosts & 3 \\
\hline $\begin{array}{l}\text { Safety/innocuity of vaccine } \\
\text { (acceptability to livestock owners) }\end{array}$ & 3 & $\begin{array}{l}\text { Availability of tests to differentiate } \\
\text { antibody responses to infection vs } \\
\text { vaccination (DIVA) }\end{array}$ & 1 & $\begin{array}{l}\text { Importance of free-living wildlife in } \\
\text { maintenance \& transmission of the } \\
\text { infection }\end{array}$ & 4 \\
\hline \multirow[t]{3}{*}{$\begin{array}{l}\text { Cost of vaccine } \& \text { vaccine } \\
\text { administration }\end{array}$} & 3 & $\begin{array}{l}\text { Availability of rapid testing systems } \\
\text { (e.g. pen-side tests) }\end{array}$ & 1 & $\begin{array}{l}\text { Extent of biological variation, including } \\
\text { antigenic variation, within the } \\
\text { infectious agent population }\end{array}$ & 3 \\
\hline & & & & $\begin{array}{l}\text { Ability of recovered animals to } \\
\text { transmit the infection (e.g. carrier } \\
\text { transmission) }\end{array}$ & 1 \\
\hline & & & & $\begin{array}{l}\text { Level of immunity \& duration in } \\
\text { recovered vertebrates }\end{array}$ & 2 \\
\hline
\end{tabular}




\section{East Coast fever}

\begin{tabular}{|c|c|c|c|c|c|}
\hline Disease management efficacy & Score & Surveillance factors & Score & Epidemiological factors & Score \\
\hline $\begin{array}{l}\text { Induction of solid immunity to } \\
\text { infection by available vaccine }\end{array}$ & 4 & $\begin{array}{l}\text { Clinical signs in domestic livestock } \\
\text { host(s) characteristic }\end{array}$ & 3 & $\begin{array}{l}\text { Persistence in \& transmission of the } \\
\text { agent by invertebrate vectors }\end{array}$ & 1 \\
\hline $\begin{array}{l}\text { Duration of vaccinal immunity/ } \\
\text { requirement for administration of } \\
\text { multiple (booster) vaccinations }\end{array}$ & 4 & $\begin{array}{l}\text { Availability of laboratory tests for } \\
\text { reliable identification of the infection } \\
\text { in live animals }\end{array}$ & 3 & $\begin{array}{l}\text { Persistence/multiplication of the agent } \\
\text { outside the bodies of susceptible hosts } \\
\text { (i.e. in the abiotic environment) }\end{array}$ & 5 \\
\hline $\begin{array}{l}\text { Amenability of vaccine to large-scale } \\
\text { application (including cold-chain } \\
\text { requirement) }\end{array}$ & 1 & $\begin{array}{l}\text { Availability of laboratory tests for } \\
\text { reliable identification of the infection } \\
\text { in dead animals }\end{array}$ & 4 & Multiplicity of livestock hosts & 5 \\
\hline $\begin{array}{l}\text { Safety/innocuity of vaccine } \\
\text { (acceptability to livestock owners) }\end{array}$ & 2 & $\begin{array}{l}\text { Availability of tests to differentiate } \\
\text { antibody responses to infection vs } \\
\text { vaccination (DIVA) }\end{array}$ & 1 & $\begin{array}{l}\text { Importance of free-living wildlife in } \\
\text { maintenance \& transmission of the } \\
\text { infection }\end{array}$ & 5 \\
\hline \multirow[t]{3}{*}{$\begin{array}{l}\text { Cost of vaccine } \& \text { vaccine } \\
\text { administration }\end{array}$} & 3 & $\begin{array}{l}\text { Availability of rapid testing systems } \\
\text { (e.g. pen-side tests) }\end{array}$ & 2 & $\begin{array}{l}\text { Extent of biological variation, including } \\
\text { antigenic variation, within the } \\
\text { infectious agent population }\end{array}$ & 2 \\
\hline & & & & $\begin{array}{l}\text { Ability of recovered animals to } \\
\text { transmit the infection (e.g. carrier } \\
\text { transmission) }\end{array}$ & 1 \\
\hline & & & & $\begin{array}{l}\text { Level of immunity \& duration in } \\
\text { recovered vertebrates }\end{array}$ & 4 \\
\hline
\end{tabular}




\section{Canine rabies}

\begin{tabular}{|c|c|c|c|c|c|}
\hline Disease management efficacy & Score & Surveillance factors & Score & Epidemiological factors & Score \\
\hline $\begin{array}{l}\text { Induction of solid immunity to } \\
\text { infection by available vaccine }\end{array}$ & 5 & $\begin{array}{l}\text { Clinical signs in domestic livestock } \\
\text { host(s) characteristic }\end{array}$ & 3 & $\begin{array}{l}\text { Persistence in \& transmission of the } \\
\text { agent by invertebrate vectors }\end{array}$ & 5 \\
\hline $\begin{array}{l}\text { Duration of vaccinal immunity/ } \\
\text { requirement for administration of } \\
\text { multiple (booster) vaccinations }\end{array}$ & 4 & $\begin{array}{l}\text { Availability of laboratory tests for } \\
\text { reliable identification of the infection } \\
\text { in live animals }\end{array}$ & 2 & $\begin{array}{l}\text { Persistence/multiplication of the agent } \\
\text { outside the bodies of susceptible hosts } \\
\text { (i.e. in the abiotic environment) }\end{array}$ & 5 \\
\hline $\begin{array}{l}\text { Amenability of vaccine to large-scale } \\
\text { application (including cold-chain } \\
\text { requirement) }\end{array}$ & 3 & $\begin{array}{l}\text { Availability of laboratory tests for } \\
\text { reliable identification of the infection } \\
\text { in dead animals }\end{array}$ & 5 & Multiplicity of livestock hosts & 4 \\
\hline $\begin{array}{l}\text { Safety/innocuity of vaccine } \\
\text { (acceptability to livestock owners) }\end{array}$ & 5 & $\begin{array}{l}\text { Availability of tests to differentiate } \\
\text { antibody responses to infection vs } \\
\text { vaccination (DIVA) }\end{array}$ & 3 & $\begin{array}{l}\text { Importance of free-living wildlife in } \\
\text { maintenance \& transmission of the } \\
\text { infection }\end{array}$ & 3 \\
\hline \multirow[t]{3}{*}{$\begin{array}{l}\text { Cost of vaccine } \& \text { vaccine } \\
\text { administration }\end{array}$} & 3 & $\begin{array}{l}\text { Availability of rapid testing systems } \\
\text { (e.g. pen-side tests) }\end{array}$ & 2 & $\begin{array}{l}\text { Extent of biological variation, including } \\
\text { antigenic variation, within the } \\
\text { infectious agent population }\end{array}$ & 4 \\
\hline & & & & $\begin{array}{l}\text { Ability of recovered animals to } \\
\text { transmit the infection (e.g. carrier } \\
\text { transmission) }\end{array}$ & 5 \\
\hline & & & & $\begin{array}{l}\text { Level of immunity \& duration in } \\
\text { recovered vertebrates }\end{array}$ & 5 \\
\hline
\end{tabular}




\section{Lumpy skin disease}

\begin{tabular}{|l|c|l|c|l|l|}
\hline \multicolumn{1}{|c|}{ Disease management efficacy } & Score & \multicolumn{1}{|c|}{ Surveillance factors } & Score & Epidemiological factors & Score \\
\hline $\begin{array}{l}\text { Induction of solid immunity to } \\
\text { infection by available vaccine }\end{array}$ & 4 & $\begin{array}{l}\text { Clinical signs in domestic livestock } \\
\text { host(s) characteristic }\end{array}$ & 4 & $\begin{array}{l}\text { Persistence in \& transmission of the } \\
\text { agent by invertebrate vectors }\end{array}$ & 1 \\
\hline $\begin{array}{l}\text { Duration of vaccinal immunity/ } \\
\text { requirement for administration of } \\
\text { multiple (booster) vaccinations }\end{array}$ & 3 & $\begin{array}{l}\text { Availability of laboratory tests for } \\
\text { reliable identification of the infection } \\
\text { in live animals }\end{array}$ & 5 & $\begin{array}{l}\text { Persistence/multiplication of the agent } \\
\text { outside the bodies of susceptible hosts } \\
\text { (i.e. in the abiotic environment) }\end{array}$ \\
\hline $\begin{array}{l}\text { Amenability of vaccine to large-scale } \\
\text { application (including cold-chain } \\
\text { requirement) }\end{array}$ & 3 & $\begin{array}{l}\text { Availability of laboratory tests for } \\
\text { reliable identification of the infection } \\
\text { in dead animals }\end{array}$ & 5 & Multiplicity of livestock hosts \\
\hline $\begin{array}{l}\text { Safety/innocuity of vaccine } \\
\text { (acceptability to livestock owners) }\end{array}$ & 4 & $\begin{array}{l}\text { Availability of tests to differentiate } \\
\text { antibody responses to infection vs } \\
\text { vaccination (DIVA) }\end{array}$ & 1 & $\begin{array}{l}\text { Importance of free-living wildlife in } \\
\text { maintenance \& transmission of the } \\
\text { infection }\end{array}$ & 4 \\
\hline $\begin{array}{l}\text { Cost of vaccine \& vaccine } \\
\text { administration }\end{array}$ & 4 & $\begin{array}{l}\text { Availability of rapid testing systems } \\
\text { (e.g. pen-side tests) }\end{array}$ & 1 & $\begin{array}{l}\text { Extent of biological variation, including } \\
\text { antigenic variation, within the } \\
\text { infectious agent population }\end{array}$ \\
\hline & & & $\begin{array}{l}\text { Ability of recovered animals to } \\
\text { transmit the infection (e.g. carrier } \\
\text { transmission) }\end{array}$ \\
\hline
\end{tabular}




\section{Rift Valley fever}

\begin{tabular}{|c|c|c|c|c|c|}
\hline Disease management efficacy & Score & Surveillance factors & Score & Epidemiological factors & Score \\
\hline $\begin{array}{l}\text { Induction of solid immunity to } \\
\text { infection by available vaccine }\end{array}$ & 4 & $\begin{array}{l}\text { Clinical signs in domestic livestock } \\
\text { host(s) characteristic }\end{array}$ & 2 & $\begin{array}{l}\text { Persistence in \& transmission of the } \\
\text { agent by invertebrate vectors }\end{array}$ & 1 \\
\hline $\begin{array}{l}\text { Duration of vaccinal immunity/ } \\
\text { requirement for administration of } \\
\text { multiple (booster) vaccinations }\end{array}$ & 4 & $\begin{array}{l}\text { Availability of laboratory tests for } \\
\text { reliable identification of the infection } \\
\text { in live animals }\end{array}$ & 3 & $\begin{array}{l}\text { Persistence/multiplication of the agent } \\
\text { outside the bodies of susceptible hosts } \\
\text { (i.e. in the abiotic environment) }\end{array}$ & 5 \\
\hline $\begin{array}{l}\text { Amenability of vaccine to large-scale } \\
\text { application (including cold-chain } \\
\text { requirement) }\end{array}$ & 3 & $\begin{array}{l}\text { Availability of laboratory tests for } \\
\text { reliable identification of the infection } \\
\text { in dead animals }\end{array}$ & 5 & Multiplicity of livestock hosts & 2 \\
\hline $\begin{array}{l}\text { Safety/innocuity of vaccine } \\
\text { (acceptability to livestock owners) }\end{array}$ & 3 & $\begin{array}{l}\text { Availability of tests to differentiate } \\
\text { antibody responses to infection vs } \\
\text { vaccination (DIVA) }\end{array}$ & 1 & $\begin{array}{l}\text { Importance of free-living wildlife in } \\
\text { maintenance \& transmission of the } \\
\text { infection }\end{array}$ & 2 \\
\hline \multirow[t]{3}{*}{$\begin{array}{l}\text { Cost of vaccine } \& \text { vaccine } \\
\text { administration }\end{array}$} & 3 & $\begin{array}{l}\text { Availability of rapid testing systems } \\
\text { (e.g. pen-side tests) }\end{array}$ & 4 & $\begin{array}{l}\text { Extent of biological variation, including } \\
\text { antigenic variation, within the } \\
\text { infectious agent population }\end{array}$ & 4 \\
\hline & & & & $\begin{array}{l}\text { Ability of recovered animals to } \\
\text { transmit the infection (e.g. carrier } \\
\text { transmission) }\end{array}$ & 5 \\
\hline & & & & $\begin{array}{l}\text { Level of immunity } \& \text { duration in } \\
\text { recovered vertebrates }\end{array}$ & 5 \\
\hline
\end{tabular}


Infectious bovine rhinotracheits

\begin{tabular}{|c|c|c|c|c|c|}
\hline Disease management efficacy & Score & Surveillance factors & Score & Epidemiological factors & Score \\
\hline $\begin{array}{l}\text { Induction of solid immunity to } \\
\text { infection by available vaccine }\end{array}$ & 4 & $\begin{array}{l}\text { Clinical signs in domestic livestock } \\
\text { host(s) characteristic }\end{array}$ & 3 & $\begin{array}{l}\text { Persistence in \& transmission of the } \\
\text { agent by invertebrate vectors }\end{array}$ & 5 \\
\hline $\begin{array}{l}\text { Duration of vaccinal immunity/ } \\
\text { requirement for administration of } \\
\text { multiple (booster) vaccinations }\end{array}$ & 3 & $\begin{array}{l}\text { Availability of laboratory tests for } \\
\text { reliable identification of the infection } \\
\text { in live animals }\end{array}$ & 4 & $\begin{array}{l}\text { Persistence/multiplication of the agent } \\
\text { outside the bodies of susceptible hosts } \\
\text { (i.e. in the abiotic environment) }\end{array}$ & 5 \\
\hline $\begin{array}{l}\text { Amenability of vaccine to large-scale } \\
\text { application (including cold-chain } \\
\text { requirement) }\end{array}$ & 3 & $\begin{array}{l}\text { Availability of laboratory tests for } \\
\text { reliable identification of the infection } \\
\text { in dead animals }\end{array}$ & 4 & Multiplicity of livestock hosts & 4 \\
\hline $\begin{array}{l}\text { Safety/innocuity of vaccine } \\
\text { (acceptability to livestock owners) }\end{array}$ & 5 & $\begin{array}{l}\text { Availability of tests to differentiate } \\
\text { antibody responses to infection vs } \\
\text { vaccination (DIVA) }\end{array}$ & 4 & $\begin{array}{l}\text { Importance of free-living wildlife in } \\
\text { maintenance \& transmission of the } \\
\text { infection }\end{array}$ & 4 \\
\hline \multirow[t]{3}{*}{$\begin{array}{l}\text { Cost of vaccine \& vaccine } \\
\text { administration }\end{array}$} & 3 & $\begin{array}{l}\text { Availability of rapid testing systems } \\
\text { (e.g. pen-side tests) }\end{array}$ & 1 & $\begin{array}{l}\text { Extent of biological variation, including } \\
\text { antigenic variation, within the } \\
\text { infectious agent population }\end{array}$ & 3 \\
\hline & & & & $\begin{array}{l}\text { Ability of recovered animals to } \\
\text { transmit the infection (e.g. carrier } \\
\text { transmission) }\end{array}$ & 2 \\
\hline & & & & $\begin{array}{l}\text { Level of immunity \& duration in } \\
\text { recovered vertebrates }\end{array}$ & 5 \\
\hline
\end{tabular}




\section{Rinderpest}

\begin{tabular}{|c|c|c|c|c|c|}
\hline Disease management efficacy & Score & Surveillance factors & Score & Epidemiological factors & Score \\
\hline $\begin{array}{l}\text { Induction of solid immunity to } \\
\text { infection by available vaccine }\end{array}$ & 5 & $\begin{array}{l}\text { Clinical signs in domestic livestock } \\
\text { host(s) characteristic }\end{array}$ & 4 & $\begin{array}{l}\text { Persistence in \& transmission of the } \\
\text { agent by invertebrate vectors }\end{array}$ & 5 \\
\hline $\begin{array}{l}\text { Duration of vaccinal immunity/ } \\
\text { requirement for administration of } \\
\text { multiple (booster) vaccinations }\end{array}$ & 5 & $\begin{array}{l}\text { Availability of laboratory tests for } \\
\text { reliable identification of the infection } \\
\text { in live animals }\end{array}$ & 4 & $\begin{array}{l}\text { Persistence/multiplication of the agent } \\
\text { outside the bodies of susceptible hosts } \\
\text { (i.e. in the abiotic environment) }\end{array}$ & 5 \\
\hline $\begin{array}{l}\text { Amenability of vaccine to large-scale } \\
\text { application (including cold-chain } \\
\text { requirement) }\end{array}$ & 4 & $\begin{array}{l}\text { Availability of laboratory tests for } \\
\text { reliable identification of the infection } \\
\text { in dead animals }\end{array}$ & 5 & Multiplicity of livestock hosts & 5 \\
\hline $\begin{array}{l}\text { Safety/innocuity of vaccine } \\
\text { (acceptability to livestock owners) }\end{array}$ & 5 & $\begin{array}{l}\text { Availability of tests to differentiate } \\
\text { antibody responses to infection vs } \\
\text { vaccination (DIVA) }\end{array}$ & 1 & $\begin{array}{l}\text { Importance of free-living wildlife in } \\
\text { maintenance \& transmission of the } \\
\text { infection }\end{array}$ & 4 \\
\hline \multirow[t]{3}{*}{$\begin{array}{l}\text { Cost of vaccine } \& \text { vaccine } \\
\text { administration }\end{array}$} & 5 & $\begin{array}{l}\text { Availability of rapid testing systems } \\
\text { (e.g. pen-side tests) }\end{array}$ & 2 & $\begin{array}{l}\text { Extent of biological variation, including } \\
\text { antigenic variation, within the } \\
\text { infectious agent population }\end{array}$ & 5 \\
\hline & & & & $\begin{array}{l}\text { Ability of recovered animals to } \\
\text { transmit the infection (e.g. carrier } \\
\text { transmission) }\end{array}$ & 5 \\
\hline & & & & $\begin{array}{l}\text { Level of immunity \& duration in } \\
\text { recovered vertebrates }\end{array}$ & 5 \\
\hline
\end{tabular}




\section{Bovine babesiosis}

\begin{tabular}{|c|c|c|c|c|c|}
\hline Disease management efficacy & Score & Surveillance factors & Score & Epidemiological factors & Score \\
\hline $\begin{array}{l}\text { Induction of solid immunity to } \\
\text { infection by available vaccine }\end{array}$ & 4 & $\begin{array}{l}\text { Clinical signs in domestic livestock } \\
\text { host(s) characteristic }\end{array}$ & 3 & $\begin{array}{l}\text { Persistence in \& transmission of the } \\
\text { agent by invertebrate vectors }\end{array}$ & 1 \\
\hline $\begin{array}{l}\text { Duration of vaccinal immunity/ } \\
\text { requirement for administration of } \\
\text { multiple (booster) vaccinations }\end{array}$ & 5 & $\begin{array}{l}\text { Availability of laboratory tests for } \\
\text { reliable identification of the infection } \\
\text { in live animals }\end{array}$ & 4 & $\begin{array}{l}\text { Persistence/multiplication of the agent } \\
\text { outside the bodies of susceptible hosts } \\
\text { (i.e. in the abiotic environment) }\end{array}$ & 5 \\
\hline $\begin{array}{l}\text { Amenability of vaccine to large-scale } \\
\text { application (including cold-chain } \\
\text { requirement) }\end{array}$ & 2 & $\begin{array}{l}\text { Availability of laboratory tests for } \\
\text { reliable identification of the infection } \\
\text { in dead animals }\end{array}$ & 4 & Multiplicity of livestock hosts & 5 \\
\hline $\begin{array}{l}\text { Safety/innocuity of vaccine } \\
\text { (acceptability to livestock owners) }\end{array}$ & 3 & $\begin{array}{l}\text { Availability of tests to differentiate } \\
\text { antibody responses to infection vs } \\
\text { vaccination (DIVA) }\end{array}$ & 1 & $\begin{array}{l}\text { Importance of free-living wildlife in } \\
\text { maintenance \& transmission of the } \\
\text { infection }\end{array}$ & 5 \\
\hline \multirow[t]{3}{*}{$\begin{array}{l}\text { Cost of vaccine } \& \text { vaccine } \\
\text { administration }\end{array}$} & 3 & $\begin{array}{l}\text { Availability of rapid testing systems } \\
\text { (e.g. pen-side tests) }\end{array}$ & 3 & $\begin{array}{l}\text { Extent of biological variation, including } \\
\text { antigenic variation, within the } \\
\text { infectious agent population }\end{array}$ & 4 \\
\hline & & & & $\begin{array}{l}\text { Ability of recovered animals to } \\
\text { transmit the infection (e.g. carrier } \\
\text { transmission) }\end{array}$ & 3 \\
\hline & & & & $\begin{array}{l}\text { Level of immunity \& duration in } \\
\text { recovered vertebrates }\end{array}$ & 5 \\
\hline
\end{tabular}




\begin{tabular}{|c|c|c|c|c|c|}
\hline Disease management efficacy & Score & Surveillance factors & Score & Epidemiological factors & Score \\
\hline $\begin{array}{l}\text { Induction of solid immunity to } \\
\text { infection by available vaccine }\end{array}$ & 4 & $\begin{array}{l}\text { Clinical signs in domestic livestock } \\
\text { host(s) characteristic }\end{array}$ & 4 & $\begin{array}{l}\text { Persistence in \& transmission of the } \\
\text { agent by invertebrate vectors }\end{array}$ & 5 \\
\hline $\begin{array}{l}\text { Duration of vaccinal immunity/ } \\
\text { requirement for administration of } \\
\text { multiple (booster) vaccinations }\end{array}$ & 4 & $\begin{array}{l}\text { Availability of laboratory tests for } \\
\text { reliable identification of the infection } \\
\text { in live animals }\end{array}$ & 2 & $\begin{array}{l}\text { Persistence/multiplication of the agent } \\
\text { outside the bodies of susceptible hosts } \\
\text { (i.e. in the abiotic environment) }\end{array}$ & 1 \\
\hline $\begin{array}{l}\text { Amenability of vaccine to large-scale } \\
\text { application (including cold-chain } \\
\text { requirement) }\end{array}$ & 3 & $\begin{array}{l}\text { Availability of laboratory tests for } \\
\text { reliable identification of the infection } \\
\text { in dead animals }\end{array}$ & 4 & Multiplicity of livestock hosts & 4 \\
\hline $\begin{array}{l}\text { Safety/innocuity of vaccine } \\
\text { (acceptability to livestock owners) }\end{array}$ & 3 & $\begin{array}{l}\text { Availability of tests to differentiate } \\
\text { antibody responses to infection vs } \\
\text { vaccination (DIVA) }\end{array}$ & 1 & $\begin{array}{l}\text { Importance of free-living wildlife in } \\
\text { maintenance \& transmission of the } \\
\text { infection }\end{array}$ & 5 \\
\hline \multirow[t]{3}{*}{$\begin{array}{l}\text { Cost of vaccine } \& \text { vaccine } \\
\text { administration }\end{array}$} & 3 & $\begin{array}{l}\text { Availability of rapid testing systems } \\
\text { (e.g. pen-side tests) }\end{array}$ & 1 & $\begin{array}{l}\text { Extent of biological variation, including } \\
\text { antigenic variation, within the } \\
\text { infectious agent population }\end{array}$ & 4 \\
\hline & & & & $\begin{array}{l}\text { Ability of recovered animals to } \\
\text { transmit the infection (e.g. carrier } \\
\text { transmission) }\end{array}$ & 4 \\
\hline & & & & $\begin{array}{l}\text { Level of immunity } \& \text { duration in } \\
\text { recovered vertebrates }\end{array}$ & 5 \\
\hline
\end{tabular}




\begin{tabular}{|c|c|c|c|c|c|}
\hline Disease management efficacy & Score & Surveillance factors & Score & Epidemiological factors & Score \\
\hline $\begin{array}{l}\text { Induction of solid immunity to } \\
\text { infection by available vaccine }\end{array}$ & 3 & $\begin{array}{l}\text { Clinical signs in domestic livestock } \\
\text { host(s) characteristic }\end{array}$ & 3 & $\begin{array}{l}\text { Persistence in \& transmission of the } \\
\text { agent by invertebrate vectors }\end{array}$ & 1 \\
\hline $\begin{array}{l}\text { Duration of vaccinal immunity/ } \\
\text { requirement for administration of } \\
\text { multiple (booster) vaccinations }\end{array}$ & 5 & $\begin{array}{l}\text { Availability of laboratory tests for } \\
\text { reliable identification of the infection } \\
\text { in live animals }\end{array}$ & 3 & $\begin{array}{l}\text { Persistence/multiplication of the agent } \\
\text { outside the bodies of susceptible hosts } \\
\text { (i.e. in the abiotic environment) }\end{array}$ & 5 \\
\hline $\begin{array}{l}\text { Amenability of vaccine to large-scale } \\
\text { application (including cold-chain } \\
\text { requirement) }\end{array}$ & 2 & $\begin{array}{l}\text { Availability of laboratory tests for } \\
\text { reliable identification of the infection } \\
\text { in dead animals }\end{array}$ & 5 & Multiplicity of livestock hosts & 4 \\
\hline $\begin{array}{l}\text { Safety/innocuity of vaccine } \\
\text { (acceptability to livestock owners) }\end{array}$ & 2 & $\begin{array}{l}\text { Availability of tests to differentiate } \\
\text { antibody responses to infection vs } \\
\text { vaccination (DIVA) }\end{array}$ & 1 & $\begin{array}{l}\text { Importance of free-living wildlife in } \\
\text { maintenance \& transmission of the } \\
\text { infection }\end{array}$ & 4 \\
\hline \multirow[t]{3}{*}{$\begin{array}{l}\text { Cost of vaccine } \& \text { vaccine } \\
\text { administration }\end{array}$} & 3 & $\begin{array}{l}\text { Availability of rapid testing systems } \\
\text { (e.g. pen-side tests) }\end{array}$ & 3 & $\begin{array}{l}\text { Extent of biological variation, including } \\
\text { antigenic variation, within the } \\
\text { infectious agent population }\end{array}$ & 3 \\
\hline & & & & $\begin{array}{l}\text { Ability of recovered animals to } \\
\text { transmit the infection (e.g. carrier } \\
\text { transmission) }\end{array}$ & 2 \\
\hline & & & & $\begin{array}{l}\text { Level of immunity \& duration in } \\
\text { recovered vertebrates }\end{array}$ & 5 \\
\hline
\end{tabular}




\begin{tabular}{|c|c|c|c|c|c|}
\hline Disease management efficacy & Score & Surveillance factors & Score & Epidemiological factors & Score \\
\hline $\begin{array}{l}\text { Induction of solid immunity to } \\
\text { infection by available vaccine }\end{array}$ & 3 & $\begin{array}{l}\text { Clinical signs in domestic livestock } \\
\text { host(s) characteristic }\end{array}$ & 3 & $\begin{array}{l}\text { Persistence in \& transmission of the } \\
\text { agent by invertebrate vectors }\end{array}$ & 5 \\
\hline $\begin{array}{l}\text { Duration of vaccinal immunity/ } \\
\text { requirement for administration of } \\
\text { multiple (booster) vaccinations }\end{array}$ & 3 & $\begin{array}{l}\text { Availability of laboratory tests for } \\
\text { reliable identification of the infection } \\
\text { in live animals }\end{array}$ & 3 & $\begin{array}{l}\text { Persistence/multiplication of the agent } \\
\text { outside the bodies of susceptible hosts } \\
\text { (i.e. in the abiotic environment) }\end{array}$ & 5 \\
\hline $\begin{array}{l}\text { Amenability of vaccine to large-scale } \\
\text { application (including cold-chain } \\
\text { requirement) }\end{array}$ & 4 & $\begin{array}{l}\text { Availability of laboratory tests for } \\
\text { reliable identification of the infection } \\
\text { in dead animals }\end{array}$ & 5 & Multiplicity of livestock hosts & 4 \\
\hline $\begin{array}{l}\text { Safety/innocuity of vaccine } \\
\text { (acceptability to livestock owners) }\end{array}$ & 4 & $\begin{array}{l}\text { Availability of tests to differentiate } \\
\text { antibody responses to infection vs } \\
\text { vaccination (DIVA) }\end{array}$ & 1 & $\begin{array}{l}\text { Importance of free-living wildlife in } \\
\text { maintenance \& transmission of the } \\
\text { infection }\end{array}$ & 3 \\
\hline \multirow[t]{3}{*}{$\begin{array}{l}\text { Cost of vaccine } \& \text { vaccine } \\
\text { administration }\end{array}$} & 4 & $\begin{array}{l}\text { Availability of rapid testing systems } \\
\text { (e.g. pen-side tests) }\end{array}$ & 4 & $\begin{array}{l}\text { Extent of biological variation, including } \\
\text { antigenic variation, within the } \\
\text { infectious agent population }\end{array}$ & 3 \\
\hline & & & & $\begin{array}{l}\text { Ability of recovered animals to } \\
\text { transmit the infection (e.g. carrier } \\
\text { transmission) }\end{array}$ & 5 \\
\hline & & & & $\begin{array}{l}\text { Level of immunity \& duration in } \\
\text { recovered vertebrates }\end{array}$ & 4 \\
\hline
\end{tabular}




\begin{tabular}{|c|c|c|c|c|c|}
\hline Disease management efficacy & Score & Surveillance factors & Score & Epidemiological factors & Score \\
\hline $\begin{array}{l}\text { Induction of solid immunity to } \\
\text { infection by available vaccine }\end{array}$ & 3 & $\begin{array}{l}\text { Clinical signs in domestic livestock } \\
\text { host(s) characteristic }\end{array}$ & 3 & $\begin{array}{l}\text { Persistence in \& transmission of the } \\
\text { agent by invertebrate vectors }\end{array}$ & 5 \\
\hline $\begin{array}{l}\text { Duration of vaccinal immunity/ } \\
\text { requirement for administration of } \\
\text { multiple (booster) vaccinations }\end{array}$ & 2 & $\begin{array}{l}\text { Availability of laboratory tests for } \\
\text { reliable identification of the infection } \\
\text { in live animals }\end{array}$ & 3 & $\begin{array}{l}\text { Persistence/multiplication of the agent } \\
\text { outside the bodies of susceptible hosts } \\
\text { (i.e. in the abiotic environment) }\end{array}$ & 2 \\
\hline $\begin{array}{l}\text { Amenability of vaccine to large-scale } \\
\text { application (including cold-chain } \\
\text { requirement) }\end{array}$ & 2 & $\begin{array}{l}\text { Availability of laboratory tests for } \\
\text { reliable identification of the infection } \\
\text { in dead animals }\end{array}$ & 4 & Multiplicity of livestock hosts & 4 \\
\hline $\begin{array}{l}\text { Safety/innocuity of vaccine } \\
\text { (acceptability to livestock owners) }\end{array}$ & 4 & $\begin{array}{l}\text { Availability of tests to differentiate } \\
\text { antibody responses to infection vs } \\
\text { vaccination (DIVA) }\end{array}$ & 1 & $\begin{array}{l}\text { Importance of free-living wildlife in } \\
\text { maintenance \& transmission of the } \\
\text { infection }\end{array}$ & 5 \\
\hline \multirow[t]{3}{*}{$\begin{array}{l}\text { Cost of vaccine } \& \text { vaccine } \\
\text { administration }\end{array}$} & 3 & $\begin{array}{l}\text { Availability of rapid testing systems } \\
\text { (e.g. pen-side tests) }\end{array}$ & 1 & $\begin{array}{l}\text { Extent of biological variation, including } \\
\text { antigenic variation, within the } \\
\text { infectious agent population }\end{array}$ & 2 \\
\hline & & & & $\begin{array}{l}\text { Ability of recovered animals to } \\
\text { transmit the infection (e.g. carrier } \\
\text { transmission) }\end{array}$ & 2 \\
\hline & & & & $\begin{array}{l}\text { Level of immunity } \& \text { duration in } \\
\text { recovered vertebrates }\end{array}$ & 5 \\
\hline
\end{tabular}




\section{Data analysis}

Disease and weighting matrices were imported into a commercial spreadsheet program (Microsoft Excel, Office Professional Plus 2010, Redmond, WA, USA) for analysis. Scores for vaccine ( $n=5)$, surveillance $(n=5)$, and epidemiological $(n=7)$ criteria were multiplied by the corresponding weighting factor and summed for each of the evaluated diseases. Diseases were ranked based on the total score with larger totals indicating more feasible eradication. Scores within each criterion were standardized creating new scores that had a mean of zero and standard deviation of 1 and multiplied by the corresponding weighting factor. Hierarchical cluster analysis was performed using Ward's linkage and squared Euclidean distance. A range of solutions were obtained for 2-5 clusters and the best solution was determined by subjectively evaluating the dendrogram produced as shown in Figure 1. The cluster assignment of the dendrogram was then assumed as the true grouping and criteria scores were compared between cluster assignments using Kruskal-Wallis tests followed by pairwise Mann-Whitney $U$ tests with Bonferroni adjustment of $P$ values for the multiple post-hoc comparisons. Discriminate analysis of the weighted (and standardized) scores was performed based on the cluster assignments to identify the specific criteria that were most influential for determining group assignments. Statistical analyses were performed blinded to the disease names using commercially available software (IBM SPSS Statistics Version 22, International Business Machines Corp., Armonk, New York, USA). Statistical results were interpreted at the $5 \%$ level of significance.

\section{RESULTS}

Summation of weighted scores for each of the 17 evaluated criteria (covering vaccination, surveillance, and epidemiology of each TAD - Table 2) enabled the ranking of diseases according to technical feasibility of eradication (Table 4). The 4 diseases that scored highest were rinderpest, canine rabies, peste des petits ruminants and the Eurasian serotypes of FMD. Cluster analysis divided the 26 diseases into three major groups (Fig. 1). All but one of the infections that are transmitted indirectly by arthropods fell into cluster $\mathrm{C}$, viz. bluetongue, African horsesickness, Rift Valley fever, heartwater, bovine anaplasmosis, East Coast fever and bovine babesiosis. The exception was lumpy skin disease which grouped with TADs in cluster B. Other diseases in cluster B were classical swine fever, Newcastle disease and, as already indicated, lumpy skin disease. The remaining diseases all fell into cluster $A$ (bovine tuberculosis, caprine brucellosis, infectious bursal disease, haemorrhagic septicaemia, sheep and goat pox, contagious bovine pleuropneumonia, contagious caprine pleuropneumonia, equine herpesvirus 1 infection, SAT serotypes of foot and mouth disease virus and paratuberculosis).

The 17 elements which constituted the technical criteria (divided between disease management efficiency, surveillance factors \& epidemiological factors) were also ranked as shown in Table 5. This revealed that elements most influential in determining which cluster individual TADs grouped into were those concerned with disease management efficiency. However, the influence of only 7 of the elements were statistically significant at the $95 \%$ confidence level (see $\mathrm{P}$ values in last column of Table 5). 
Table 4: Feasibility ranking of evaluated diseases based on the sum of weighted criteria scores

\begin{tabular}{|c|c|c|c|c|c|}
\hline \multirow[b]{2}{*}{ Rank } & \multirow[b]{2}{*}{ Disease (number ID) } & \multicolumn{3}{|c|}{ Sum weighted criteria score } & \multirow[b]{2}{*}{ Total } \\
\hline & & Vaccine & Surveillance & Epidemiology & \\
\hline 1 & Rinderpest (21) & 135 & 85 & 241 & 461 \\
\hline 2 & Canine rabies (17) & 117 & 72 & 221 & 410 \\
\hline 3 & Peste des petits ruminants (4) & 99 & 74 & 228 & 401 \\
\hline 4 & Foot \& mouth disease - E (11) & 94 & 108 & 188 & 390 \\
\hline 5 & Infectious bovine rhinotracheitis (20) & 102 & 85 & 199 & 386 \\
\hline 6 & Newcasle disease (25) & 97 & 76 & 208 & 381 \\
\hline 7 & Classical swine fever (2) & 109 & 67 & 204 & 380 \\
\hline 8 & Equine influenza (10) & 95 & 68 & 213 & 376 \\
\hline 9 & Lumpy skin disease (18) & 100 & 91 & 185 & 376 \\
\hline 10 & $\begin{array}{l}\text { Contagious bovine pleuropneumonia } \\
\text { (14) }\end{array}$ & 87 & 49 & 236 & 372 \\
\hline 11 & Bovine babesiosis (22) & 101 & 77 & 191 & 369 \\
\hline 12 & Infectious bursal disease (23) & 99 & 62 & 203 & 364 \\
\hline 13 & $\begin{array}{l}\text { Contagious caprine pleuropneumonia } \\
\text { (6) }\end{array}$ & 87 & 52 & 208 & 347 \\
\hline 14 & Rift Valley fever (19) & 99 & 71 & 168 & 338 \\
\hline 15 & Bovine tuberculosis (5) & 104 & 64 & 161 & 329 \\
\hline 16 & Anthrax (1) & 97 & 53 & 175 & 325 \\
\hline 17 & Bovine anaplasmosis (24) & 88 & 74 & 163 & 325 \\
\hline 18 & Haemorrhagic septicaemia (26) & 77 & 65 & 180 & 322 \\
\hline 19 & Caprine brucellosis (7) & 99 & 46 & 170 & 315 \\
\hline 20 & Blue tongue (3) & 90 & 62 & 161 & 313 \\
\hline 21 & Equine herpesvirus - 1 (8) & 70 & 44 & 192 & 306 \\
\hline 22 & East Coast fever (16) & 84 & 67 & 155 & 306 \\
\hline 23 & Foot \& mouth disease $-S(9)$ & 79 & 94 & 131 & 304 \\
\hline 24 & African horsesickness (12) & 81 & 54 & 155 & 290 \\
\hline 25 & Heartwater (13) & 91 & 62 & 137 & 290 \\
\hline 26 & Paratuberculosis (15) & 56 & 57 & 148 & 261 \\
\hline
\end{tabular}


Table 5: Descriptive statistics and comparisons of scores among assigned clusters

\begin{tabular}{|c|c|c|c|c|c|}
\hline \multirow[b]{3}{*}{ Technical criterion } & \multirow{3}{*}{$\begin{array}{c}\text { Importance } \\
\text { rank }\end{array}$} & \multicolumn{3}{|c|}{ Cluster assignment } & \multirow{3}{*}{$\begin{array}{c}\text { P } \\
\text { value* }\end{array}$} \\
\hline & & $A(n=10)$ & $B(n=9)$ & $C(n=7)$ & \\
\hline & & $\begin{array}{l}\text { Median } \\
\text { (range) }\end{array}$ & $\begin{array}{l}\text { Median } \\
\text { (range) }\end{array}$ & $\begin{array}{l}\text { Median } \\
\text { (range) }\end{array}$ & \\
\hline \multicolumn{6}{|l|}{ Disease management efficacy } \\
\hline Induction of solid immunity to infection & 9 & $3(1,4)$ & $4(3,5)$ & $4(3,4)$ & 0.085 \\
\hline Duration of vaccinal immunity & 2 & $3(1,5)$ & $3(2,5)$ & $4(3,5)$ & 0.131 \\
\hline Amenability of vaccine to large-scale application & 6 & $2.5^{\mathrm{a}, \mathrm{b}}(2,4)$ & $3^{a}(3,4)$ & $2^{b}(1,3)$ & 0.006 \\
\hline Vaccine safety and acceptability to livestock owners & 4 & $3^{a, b}(2,5)$ & $5^{\mathrm{a}}(3,5)$ & $3^{b}(2,3)$ & 0.002 \\
\hline Cost of vaccine and vaccine administration & 3 & $3(3,4)$ & $3(3,5)$ & $3(2,4)$ & 0.330 \\
\hline \multicolumn{6}{|l|}{ Surveillance factors } \\
\hline Characteristic clinical signs in domestic livestock hosts & 13 & $3(2,4)$ & $3(2,4)$ & $3(2,3)$ & 0.339 \\
\hline Availability of laboratory tests for reliable diagnosis in live animals & 7 & $2^{a}(1,5)$ & $4^{b}(2,5)$ & $3^{a, b}(1,4)$ & 0.039 \\
\hline Availability of laboratory tests for reliable diagnosis in dead animals & 11 & $4^{a}(4,4)$ & $5^{b}(3,5)$ & $5^{b}(4,5)$ & 0.010 \\
\hline Availability of tests to differentiate antibody responses to vaccination & 10 & $1(1,3)$ & $1(1,5)$ & $1(1,1)$ & 0.088 \\
\hline
\end{tabular}




\section{Epidemiological factors}

Persistence in and transmission of the agent by invertebrate vectors

$\begin{array}{ccccc}1 & 5^{\mathrm{a}}(5,5) & 5^{\mathrm{a}}(1,5) & 1^{\mathrm{b}}(1,1) & <0.001 \\ 8 & 3^{\mathrm{a}(1,5)} & 5^{\mathrm{a}, \mathrm{b}}(3,5) & 5^{\mathrm{b}}(4,5) & 0.019 \\ 14 & 3.5(1,5) & 4(2,5) & 4(2,5) & 0.481 \\ 17 & 4.5(1,5) & 4(3,5) & 3(2,5) & 0.418 \\ 15 & 3.5(1,5) & 4(2,5) & 2(2,4) & 0.170 \\ 5 & 2^{\mathrm{a}(1,5)} & 5^{\mathrm{b}}(2,5) & 3^{\mathrm{a}, \mathrm{b}}(1,5) & 0.020 \\ 16 & 4(2,5) & 4(3,5) & 5(4,5) & 0.129\end{array}$

Persistence/multiplication of agent outside the bodies of susceptible hosts

Multiplicity of livestock hosts

Importance of wildlife in the maintenance and transmission of infection

Extent of biological and antigenic variation within the infectious agent

Ability of recovered animals to transmit the infection

Level of immunity and duration in recovered vertebrates

*Based on Kruskal-Wallis tests. Medians without superscripts in common are significantly different based on pairwise Mann-Whitney U tests after

Bonferroni correction of $\mathrm{P}$ values. 


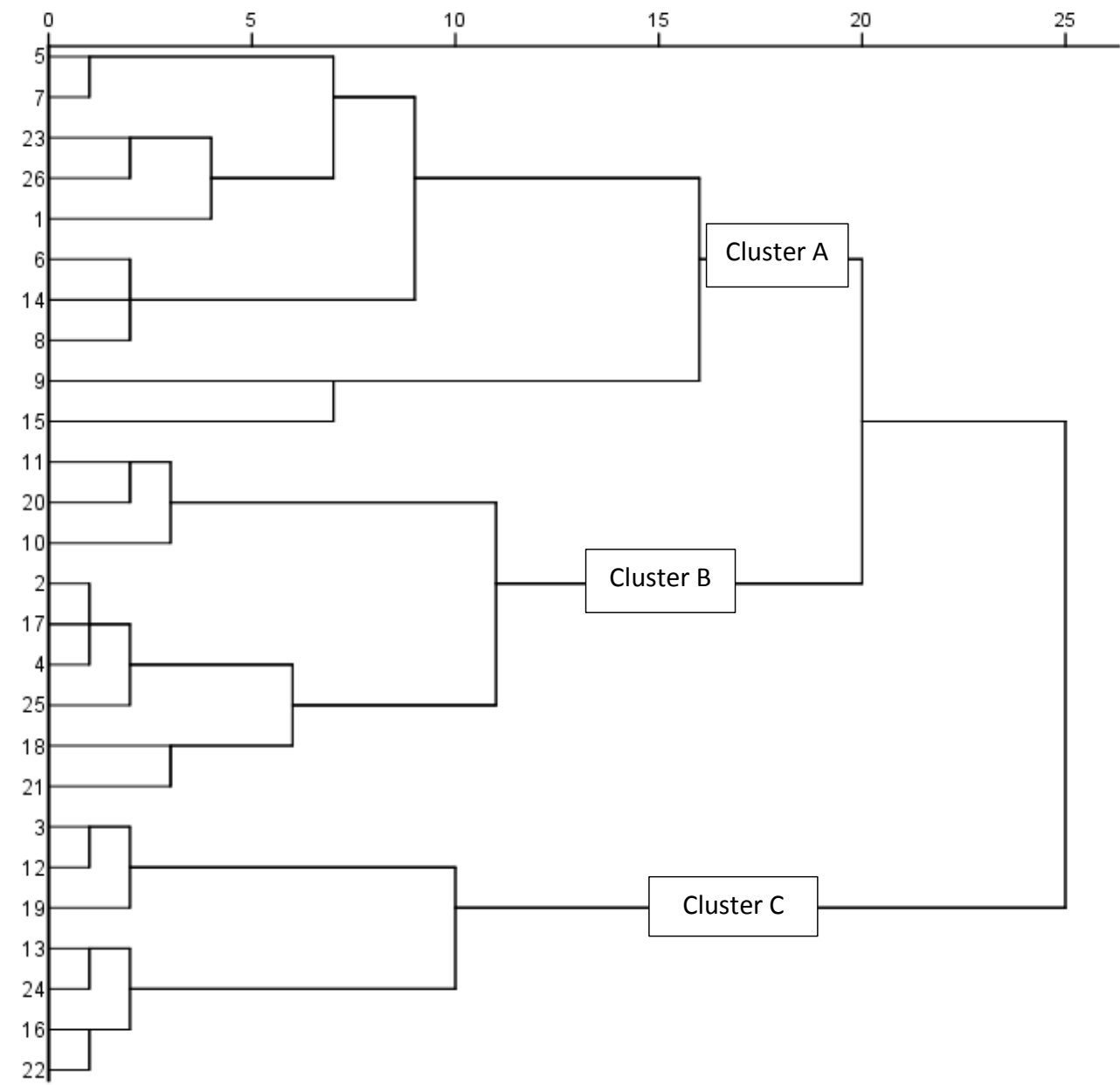

Figure 1 : Disease similarity based on cluster analysis of weighted standardized criteria scores.

\section{DISCUSSION}

Before any TAD is considered as a candidate for either regional elimination or global eradication two primary considerations are vital: (1) technical amenability to eradication and (2) assurance that the long-term benefits will exceed the short-term costs of an eradication programme and also that societies required to bear the brunt of the financial and other costs will be prepared to do so. This study only addresses the first of these requirements for 25 diseases based on a potential mass vaccination programme that would need to be time-bound (i.e. covering a finite number of years). The $26^{\text {th }}$ disease - rinderpest - was included in the study as a yard-stick because it has already been eradicated globally. 
It is evident to us that in evaluating the technical requirements for eradicability of different TADs, it is important to have an unbiased system for objective evaluation. Development of such a system was therefore the major objective of this study. We are furthermore fully aware that scoring of the elements which comprise the three major criteria for each disease is subjective, as is the weighting accorded to each element. Therefore, the scores we have awarded are potentially biased, and it is consequently likely that other individuals or groups of experts would assign different scores. Although the key to using this approach is to obtain reliable expert opinion our aim was simply to develop a system within which such opinion can be objectively focused, rather than providing accurate categorization of TADs. We anticipate therefore that this system will provide a framework which could be further developed and refined.

Using the criteria and weighting of elements shown in Table 2 we ranked the 26 TADs on the basis of likely eradicability (Table 4). Unsurprisingly, TADs commonly considered as amenable to eradication ranked highest, viz. rinderpest, canine rabies, the Eurasian lineage of FMD viruses and peste des petits ruminants. The other major lineage of FMD viruses (SAT serotypes) was adjudged less amenable to eradication. This difference between these two lineages has in the past been ascribed mainly to the fact that SAT serotype viruses appear to have evolved in African buffalo and are maintained independently of other cloven-hoofed species (Thomson et al., 20013; Thomson et al., 2004). On the other hand, as shown in Table 5, this element (importance of wildlife in the maintenance and transmission of infection) ranked lowest among the 17 technical elements influencing the clustering of the 26 TADs. The inference is that other elements were more important in placing the two lineages of FMD viruses into different clusters.

All arthropod-transmitted TADs, with the exception of lumpy skin disease, grouped together in cluster $\mathrm{C}$. This is understandable because the ranking of this factor (persistence in and transmission of the agent by invertebrate vectors) was highest among the 17 elements which comprised the technical criteria (Table 5). Cluster B contained diseases generally considered eradicable (rinderpest, canine rabies, peste des petits ruminants and the Eurasian lineage of FMD viruses). The implication is that the other diseases in this cluster (classical swine fever, Newcastle disease and lumpy skin disease) are possibly also amenable to eradication. Whether that is so from a technical perspective in the case of lumpy skin disease requires further consideration because of recent findings indicating that it is a tick-transmitted infection (Tuppurainen et al., 2013).

TADs in cluster A (anthrax, bovine tuberculosis, contagious caprine pleuropneumonia, equine herpesvirus 1, caprine brucellosis, SAT serotypes of FMD, contagious bovine pleuropneumonia, paratuberculosis, infectious bursal disease \& haemorrhagic septicaemia) clearly differ from the other two clusters. As shown in Table 4, these diseases are predominantly in the lower half of the list which suggests that, from a technical perspective, they would be more difficult to eradicate.

An implication of this study is that consideration needs to be given by the OIE to the provision of alternative, i.e. non-geographic sanitary risk trade standards, for TADs which are fundamentally technically difficult to eliminate or eradicate.

\section{REFERENCES}

Amanfu, W., 2009, Contagious bovine pleuropneumonia (lungsickness) in Africa, Onderstepoort Journal of Veterinary Research 76, 13-17. 
Anderson, J., Baron, M., Cameron, A., Kock, R., Jones, B., Pfeiffer, D., Mariner, J., McKeever, D., Oura, C., Roeder, P., Rossiter, P. \& Taylor, W., 2011, Rinderpest eradicated, what next? Veterinary Record 169, 10-11.

Anon, 2013, Disease eradication, History of Vaccines, The College of Physicians of Philadelphia, viewed 6 December 2013, http://www.historyofvaccines.org/content/articles/disease-eradication.

Baron, M.D., Parida, S. \& Oura, C.L., 2011, Peste des petits ruminants: a suitable candidate for eradication? Veterinary Record 169, 16-21.

Carter Center, 2008, Diseases considered as candidates for global eradication by the International Task Force for Disease Eradication, viewed 6 December 2013, http://www.cartercenter.org/resources/pdfs/news/health publications/itfde/updated disease candidate ta ble.pdf

De Vries, J., 2008, Goats for the poor: some keys to successful promotion of goat production among the poor, Small Ruminant Research 77, 221-224.

Dowdle, W.R., 1998.'The principles of disease elimination and eradication', Bulletin of the World Health Organisation 78 (suppl. 2), 22-25.

Edwards, S., Fukusho, A., Lefevre, P-C., Pejsak, Z., Roehe., P. \& Westergaard, J., 2000. Classical swine fever: the global situation. Veterinary Microbiology, 73, 103-119.

FAO, 2012, Lessons learned from the eradication of rinderpest for controlling other transboundary animal diseases, Proceedings of the GREP Symposium and High-level Meeting, 12-15 October 2010, Rome, Italy. FAO Animal Production and Health Proceedings, No 15, Rome, Italy.

Gwaze, F.R., Chimonyo, M. \& Dzama, K., 2009, Variation in the functions of village goats in Zimbabwe and South Africa, Tropical Animal Health and Production 41, 1381-1391.

IRIN, 2011, Is eradicating livestock diseases the best way forward?, viewed 7 December 2013, http://www.theguardian.com/global-development/2011/jun/22/eradicating-livestock-diseases/print

Knowles, N.J. \& Samuel, A.R., 2003. Molecular epidemiology of foot-and-mouth disease virus. Virus Research $91,65-80$.

Liu, J., Sepideh, M., Gosling, R.D. \& Feachem, R.D.A., 2013, Malaria eradication : is it possible ? Is it worth it ? Should we do it ? The Lancet Global Health, Volume 1, Issue 1, e2-e3, July 2013, doi : 10.1016/S2214109X(13)70002-0, $\quad$ viwed 6 December 2013, http://download.thelancet.com/pdfs/journals/langlo/PIIS2214109X13700020.pdf.

Mariner, J.C., House, J.A., Mebus, C.A., Sollod, A.E., Chibeu, D., Jones, B.A., Roeder, P.L., Admassu, B. \& van 't Klooster, G.G.J., 2012, Rinderpest eradication : appropriate technology and social interventions, Science 337, 1309-1312.

Marobela-Raborokgwe, C., 2011, Contagious bovine pleuropneumonia in Botswana : experience with control, eradication, prevention and surveillance, Veterinaria italiana 47 (4), 397-405.

Mendis, K., Rietveld, A., Warsame, M., Bosman, A., Greenwood, B. \& Wernsdorfer, W.H., 2009, From malaria control to eradication : the WHO perspective, Tropical Medicine and International Health 14 (7), 1-7.

Miller, M., Barrett, S. \& Henderson, D.A., 2006, Control or eradication, in Jamison DT, Breman JG, Measham AR et al. (eds), Disease control priorities in developing countries, pp.1163-1176, World Bank, Washington DC, viewed on 6 December 2013, http://www.ncbi.nlm.nih.gov/books/NBK11763/pdf/ch62.pdf. 
Ocaido, M., Muwazi, R.T. \& Opuda-Osibo, j., 2009, Financial analysis of livestock production systems around Lake Mburo National Park, in South-Western Uganda, Livestock Research for Rural Development 21 (5)

OIE, 2011a, No more deaths from rinderpest, viewed 7 December 2013, http://www.oie.int/for-themedia/press-releases/detail/article/no-more-deaths-from-rinderpest/

OIE, 2011b, Resolution No. 18, Declaration of global eradication of rinderpest and implementation of follow-up measures to maintain world freedom from rinderpest, viewed on 7 December 2013, http://www.oie.int/fileadmin/Home/eng/Media Center/docs/pdf/RESO 18 EN.pdf.

OIE, 2012, FAO/OIE Global Conference on foot and mouth disease control, 27-29 June 2012, Bangkok, Thailand, viewed 08 December 2013, http://www.oie.int/fileadmin/Home/eng/Conferences Events/docs/pdf/recommendations/A FMD Recomme ndations Bankok 2012.pdf

OIE FAO, 2013. The global foot and mouth disease control strategy, viewed on 8 December 2013, http://www.fao.org/docrep/015/an390e/an390e.pdf

OIE WAHID, 2013, Event summary: Peste des petits ruminants, Angola, viewed 12 December 2013, http://www.oie.int/wahis 2/public/wahid.php/Reviewreport/Review/viewsummary?reportid=12408

Penrith, M.-L. \& Thomson, G.R., 2004, Special conditions affecting the control of livestock diseases in subSaharan Africa, in J.A.W Coetzer \& R.C. Tustin (eds), Infectious diseases of livestock ( ${ }^{\text {nd }}$ edn), Vol. 1, pp. 171177, Oxford University Press, Cape Town.

Perry, B. \& Grace, D., 2009, The impact of livestock diseases and their control on growth and development processes that are pro-poor, Philosophical Transactions of the Royal Society B 364, 2643-2655.

Roeder, P.L., 2010, Lessons learned from GREP for PPR, and tools for PPR eradication, pp. 127-132, in FAO, 2012, Lessons learned from the eradication of rinderpest for controlling other transboundary animal diseases. Proceedings of the GREP Symposium and High-Level Meeting, 12-15 October 2010, Rome, Italy, FAO Animal Production and Health Proceedings, No 15, Rome, Italy.

Roeder, P.L., 2011, Rinderpest: the end of cattle plague, Preventive Veterinary Medicine 102, 98-106.

Rweyemamu, M., Roeder, P., Mackay, D., Sumption, K., Brownlie, J., Leforban, Y., Valarcher, J.-F., Knowles, N.J. \& Saraiva, V., 2003, Epidemiological patterns of foot-and-mouth disease worldwide, Transboundary and Emerging Diseases 55, 57-72.

Safari J., Mtenga, L., Eik, L.O., Sundstol, F. \& Johnsen, F.H., 2008, Analysis of three goat production systems and their contribution to food security in semiarid areas of Morogoro, Tanzania, Livestock Research for Rural Development 20 (5).

Singh, R.K., Balamurugan, V., Bhanuprakash V., Sen, A., Saravanan, P. \& Yadav, M.P., 2009, Possible control and eradication of peste des petits ruminants from India: technical aspects, Veterinaria italiana 45, 449-462.

Slingenbergh, J., 2010, After rinderpest, what next? pp. 139-140, in FAO, 2012, Lessons learned from the eradication of rinderpest for controlling other transboundary animal diseases. Proceedings of the GREP Symposium and High-Level Meeting, 12-15 October 2010, Rome, Italy, FAO Animal Production and Health Proceedings, No 15, Rome, Italy.

Sutmoller, P., Barteling, S., Casas Olascoaga, R. \& Sumption, K.J., 2003. Control and eradication of foot-andmouth disease. Virus Research, 91, 101-144. 
Thomson, G.R., 2009. Currently important animal disease management issues in sub-Saharan Africa. Onderstepoort Journal of Veterinary Research, 76, 129-134.Thomson, G.R., Vosloo, W. \& Bastos, A.D.S., 2003. Foot and mouth disease in wildlife. Virus Research, 91, 145-161.

Thomson, G.R. \& Bastos, A.D.S., 2004, Foot-and-mouth disease, in J.A.W Coetzer \& R.C. Tustin (eds), Infectious diseases of livestock ( $2^{\text {nd }}$ edn), Vol. 2, pp. 1324-1365, Oxford University Press, Cape Town.

Thomson, G.R., Penrith, M.-L., Atkinson, M.W., Atkinson, S.J., Cassidy, D. \& Osofsky, S.A., 2013a, Balancing livestock production and wildlife conservation in and around Southern Africa's transfrontier conservation areas, Transboundary and Emerging Diseases 60, 507-515.

Thomson, G.R., Penrith, M.-L., Atkinson, M.W., Thalwitzer, S., Mancuso, A., Atkinson, S.J. \& Osofsky, S.A., 2013b, International standards for commodities and products derived from animals: the need for a system that integrates food safety and animal disease management, Transboundary and Emerging Diseases 60, 492506.

Tuppurainen, E.S., Lubinga, J.C., Stoltz, W.H., Troskie, M., Carpenter, S.T., Coetzer, J.A., Venter, E.H. \& Oura, C.A., 2013. Evidence of vertical transmission of lumpy skin disease virus in Rhipicephalus decoloratus ticks, Ticks and tick-borne diseases, 4, 329-333.

Vosloo, W., Bastos, A.D.S, Sangare, O., Hargreaves, S.K. \& Thomson, G.R., 2002, Review of the status and control of foot and mouth disease in sub-Saharan Africa, Revue scientifique et technique, Office international des Épiaooties 21, 437-449.

Weaver, G.V., Domenech, J., Thiermann, A.R. \& Karesh, W.B., 2013, Foot and mouth disease: a look from the wild side, Journal of Wildlife Diseases 49, 759-785.

WHO, 1980, World health Organization declares smallpox eradicated, viewed on 7 December 2013, http://www.pbs.org/wgbh/aso/databank/entries/dm79sp.html .

WHO, 2013, WHO heralds "new phase" in the fight against neglected tropical diseases, viewed on 6 December 2013, http://www.who.int/mediacentre/news/releases/2013/ntds report 20130116/en/index.html .

Windsor, R.S., 2000, The eradication of contagious bovine pleuropneumonia from south western Africa, Annals of the New York Academy of Science 916, 326-332. 